\title{
スルースゲートの閉鎖に伴い発生する段波の 水理実験とその数值計算
}

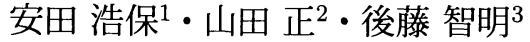 \\ 1正会員 修士 (工学) 独立行政法人北海道開発土木研究所河川研究室 ( ⿳ 062-8602 札幌市豊平区平岸 1 条 3-1-34) \\ ${ }^{2}$ 正会員 工博 中央大学教授 理工学部土木工学科 \\ 正会員 工博 前東海大学教授 工学部土木工学科
}

\begin{abstract}
ゲートの閉鎖に伴い発生する段波の特性を考察することを目的に水理実験とその数値計算を行った. まず，水 理実験を行い, その結果からゲートの操作方法に関するパラメータを導入することでゲートを緩やかに降下させ た場合に発生する段波がゲートの閉鎖後の間もない段階から波状性を伴うか否かの判定が可能なことを示した. つぎに, 浅水理論式と非線形分散波理論式を基礎式とした 2 つの数值解析モデルを構築して実験値の再現計算 を行った結果, 非線形分散波理論式に基づく数值解析モデルはいずれの実験ケースの波形や波速も精度良く再 現できることを示した. 最後に，この数值解析モデルを利用して長大な水路を仮想した数值実験を行い，ゲー トの操作方法の違いが伝播に伴う段波の変形過程や保存波への遷移に及ぼす影響について考察した.
\end{abstract}

Key Words : undular bore, nonlinear dispersive wave theory, coefficient of discharge, gate operation

1.はじめに

洪水制御の方法の一つに河道に設置されたゲートの 開閉操作がある.しかし，このゲートの開口高を操作 して急激に流量を減少させると上流へ向かう段波が発 生する. その段波はゲートの操作方法の違いによって, 緩やかな段波面を形成する場合と急峻な段波面を形成 する場合があるが，いずれにしても長い距離を伝播す るに従い波状段波に遷移していく．波状段波の波高は 変形前の段波の波高に比べて大きくなるため，場合に よっては河川堤防を越流して氾濫する危険性が考えら れる. この他, 霞ヶ浦の出口に設置された常陸川水門 ではその開閉に伴い，連結する複数の水域間において 連成振動が発生し, 北浦の一部では漁網が流されたと いう被害報告がある．その原因は水門の閉鎖に伴い発 生した遡上波であると推測されており1)，このような問 題に対しても本研究を応用することが可能であると考 えられる。

本研究は, ゲートの閉鎖に伴い発生する段波の特性 を考察することを目的としており, 以下の手順で研究 を進めた. まず, ゲートからの流出量が段波波形に大き く影響すると考えられることからゲートの流量係数 $C$ の検証に関する水理実験を行った. そして, Henry が 導いている流量係数 $C$ の理論解 2$)$ と著者らの実験值を 比較した. つぎに, 自由落下に従いゲートを閉鎖させ る急閉の実験ケースとモータの動力を利用して等速で ゲートを降下させる緩閉の実験ケースを設定したゲー
トの閉鎖に伴い発生する段波の水理実験を行い，その 特性について多面的に考察をした. さらに, 浅水理論 式とこの式に分散性を考慮した非線形分散波理論式を 基礎式とした数值解析モデルを構築して実験值の再現 計算を行った. 最後に, この数值解析モデルを利用し， ゲートの閉鎖方法の違いが長距離を伝播した場合の段 波の変形過程や波高に及ぼす影響を調べるために長大 な水路を仮想した数值実験を行った。

なお，様々な形式のゲートが存在するが，本研究の 水理実験では実際の河川で最も多く利用されているス ルースゲートタイプのゲートを模擬した．また，本論 文では段波の諸量に関する各記号を図-1に示すとおり 定義した.

\section{2. 段波に関する既往の研究}

\section{（1）段波の変形理論に関する既往の研究}

段波の変形を定量的に把握する研究は古く, 1865 年 に Bazin ${ }^{3)}$ により始められている. 彼は，段波はその進 行につれて分散波列を形成し，その分散第 1 波の波高 増幅率 $\eta_{\max } / \eta_{b}$ は 1.5 になることを実験的に示した.

Boussinesq ${ }^{4)}$ は水粒子の鉛直方向加速度を考慮した有 限振幅波理論の式を与え, 波形曲率の効果により波状 段波が発生すると説明している. 彼のこの式が現在も 分散性を伴う現象を説明する基礎理論式として用いら れている.

Favre $^{5)}$ は静水状態となっている水平床矩形水路の中 


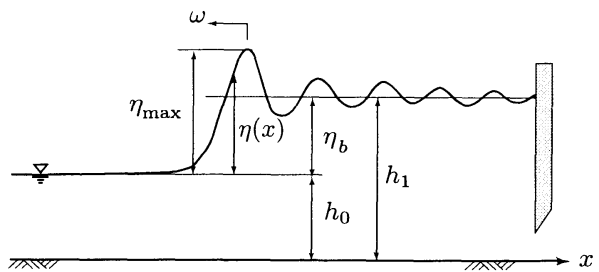

$h_{0} ;$ ゲートを水に浸す前の水深

$h_{1} ;$ 段波平均水深 $\omega ;$ 段波波速

図-1 段波の諸量に関する各記号の定義

にゲートを設置して水位差を付け，そのゲートを引き 抜くことで段波を発生させ, $\eta_{b} / h_{0}$ と $\eta_{\max } / \eta_{b}$ の関係を 整理した. その結果から $\eta_{b} / h_{0}$ が 0.28 の時に $\eta_{\max } / \eta_{b}$ は最大值の 2.06 になることを示した．また，段波は終 局的には保存波に遷移することを認めている.

Keulegan \& Patterson $\left.{ }^{6}\right)$ は Bazin の実験結果の再整 理を行い, $\eta_{b} / h_{0}$ が 0.61 よりも小さい時に波状段波が 形成され，それはクノイド波に漸近していき，その波 速はクノイド波の波速によく一致することを示してい る.これらのことから, 分散波は終局的にはクノイド 波に遷移すると結論している．また，波状段波の発生 限界は $\eta_{\max } / \eta_{b}$ が 1.5 以下であることを理論的に導い ている.

Benjamine \& Lighthill ${ }^{7)}$ はクノイド波理論を用いて， 質量，運動量，エネルギーの総和が釣り合うときに段 波からクノイド波が形成されることを示し，分散波が 形成されるのは波先部の擾乱によるものであるとした.

Chester ${ }^{8)}$ や Johnson ${ }^{9)}$ は分散波の形成原因を Benjamine \& Lighthill が波先部の擾乱と考えたのに対し， 底面境界層のエネルギ一散逸によるものであるとし, 波 状段波の発生条件を理論的に $\eta_{b} / h_{0}$ が 0.79 以下である とした. また, Johnson ${ }^{9), 10)}$ はこれらの現象を記述する 数学モデルとして KdV-Burgers 方程式を示したほか, 理論的に波状段波の発生限界は Froude 数が 1.6 以下で あるとした。

Peregrine $^{11)}$ は鉛直方向加速度により生ずる水平方 向圧力勾配が分散波を発生させると説明した。 また, KdV(Korteweg-deVries) 式 ${ }^{13)}$ を基礎式とした数值計算 を行い, 段波の変形過程の計算例を示した. さらに, $\mathrm{KdV}$ 式や Boussinesq 式4)が水平床の式であるのに対 し，一様斜面上における線形の分散項を有する式を導 いた ${ }^{12)}$. ただし, 波高水深比が大きくなる場合ではこ の式は理論, 数值計算のいずれの面からも適当でない ことを後藤 ${ }^{14)}$ は指摘している.

室田・岩田 ${ }^{15)}$ は Boussinesq の波形曲率を考慮した式 を基礎式とした理論解析と水理・数值実験を行い, 段 波の波状段波への遷移は波形曲率が伝達項として作用
しているためと結論している. しかし，この研究で示 されている分散機構では非線形分散波の分散機構を満 足に説明することはできない. 非線形分散波の分散機 構の解説は後藤16)によるものが詳しい.

松冨 ${ }^{17)}$ は 1 次元水平床で段波の下流側流速が 0 の場 合の波状段波の発生条件を従来の理論・実験結果の検 討と新たな水理実験を行い, $\eta_{b} / h_{0}$ が $0.61 \sim 0.64$ 程度 以下であると結論した.

前述の通り, 既往の研究は伝播に伴う段波の変形過 程や，波状段波の発生条件に関して実験的なあるいは 理論的な考察が行われているものの, これらの研究は ゲート急開時に発生する段波に対して行われたもので ある. また, 本研究が対象とするゲートの開鎖に伴い 発生する段波に関する知見の蓄積は少なく, 既往研究 により得られた知見をすぐさま本研究が対象とするよ うな現象に適用することは得策ではないと考えられる.

\section{(2) 段波の数値計算に関する既往の研究}

段波の数值計算手法に関する研究は浅水理論式を基 礎式としたものが多い, 岩崎・阿部18),19),20) ら, 岩佐・ 多田 ${ }^{21)}$ は, その数值解析法に特性曲線法を用いた計算 法を, 中村・福嶋 ${ }^{22}$ は数值解析法に重み付きの陰差分 法で安定に計算する方法を示している. 後藤・首藤 ${ }^{23)}$ は河川の湾曲部や湾などの複雑な地形に適した直交曲 線座標系に座標変換した浅水理論式を用いる計算法を 示し, 湾曲部を通過する段波はその内側と外側で大き な水位差が現れることを指摘している. 宮崎・史 ${ }^{24)}$ は 数值解析法に有限体積法を用いて, 1993 年の北海道南 西沖地震時に発生した津波の河川遡上の再現計算を行っ ている.この他, 松富ら ${ }^{25)}$ は移動床の影響を考慮した ダム破壞流れに関する 2 次元の汇濫計算法について示 している. いずれにしても，これらのような浅水理論 式を基礎式とした計算では段波の不連続面が伝播する だけで, 段波の伝播に伴う波高増幅などの変形過程を 得ることができない問題点があるほか, 数值的なギブ 不振動の発生に対して何らかの対策を行う必要がある.

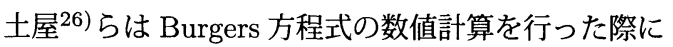
発生する数值粘性・数值的なギブス振動を除去できる 計算法を示し, それを用いて Bore front の伝播と変形 に関する数值計算が可能であることを示した. ただし， この方程式では段波の伝播に伴う分散効果について考 慮できないという問題点がある.

Tsuji et al. ${ }^{27)}$ は Johnson ${ }^{9), 10)}$ が示した段波波高の減 衰と分散の両方を考慮している KdV-Burgers 方程式を 数值的に解き, 拡散項のエネルギー散逸係数と計算波 形の $\eta_{\max } / \eta_{b}$ の関係を整理した。この研究で示された 河川を遡上する津波の解析法は実用性に富む解析法の 一つであると考えられる．また，彼らは波状段波では 




(a)もぐり流出

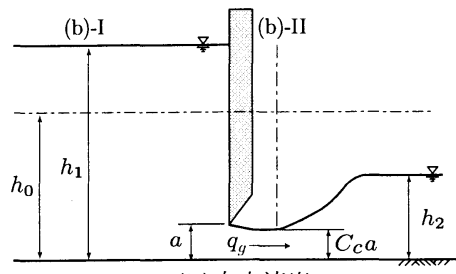

(b) 自由流出

図-2 水理諸量の定義

$\eta_{\max } / \eta_{b}$ が 1.5 以下になることを実験的に示している.

磯部ら ${ }^{28), 29)}$ は, 自由表面が多価関数となる複雑な流 れを取り扱える VOF 法と SMAC 法に基づいた数值解 析モデルを示している，さらに，高橋ら ${ }^{30)}$ はこれを用 いて，造波板を用いる方法とゲート急開によるダム破 壊を模擬した方法の 2 つの方法で段波を発生させてこ れらについて検討を行い，計算結果と水理実験を比較 して妥当な結果が得られることを報告している.

前述の通り，津波の河川遡上やダム破壊問題のよ うな水と空気が激しく混合する，いわゆる Turbulent(strong)bore を対象とした数值解析に関する研究 が多く行われている. 一方, 本研究で取り扱うような Undular(weak)bore の特性を検討した研究例は少ない ようである.このような段波は，発生時にこそ緩やか な段波面を形成しているだけであるものの，伝播に従 い波高を増幅しながら波状段波に遷移していく．この ため, 工学上, 波状段波の波高や変形過程を知ること は大変重要であるだけでなく，既往の研究で明らかに されている知見が適用できるか否かを検討する必要が ある.このような視点から，本研究では，ゲートの閉 鎖に伴い発生する段波の特性や波状段波の発生条件な どを考察することを目的に水理実験および数值実験を 行った.

\section{3. ゲート流量係数の検証に関する水理実験}

\section{（1）実験概要と条件}

ゲートの操作に伴い発生する段波の数值解析を行う 場合，ゲートからの流出量は段波波形に直接影響する ことから使用する支配方程式が適切であるだけでなく，

\begin{tabular}{c|c|c}
\hline 水理諸量 & 範囲 & 刻み間隔 \\
\hline Froude 数 $F r_{0}$ & $0.05 \sim 0.25$ & 0.05 \\
\hline 水深 $h_{0}(\mathrm{~m})$ & $0.15,0.20$ & 0.05 \\
\hline ゲートの開口高 $a(\mathrm{~m})$ & $0.01 \sim 0.13$ & 0.01 \\
\hline
\end{tabular}
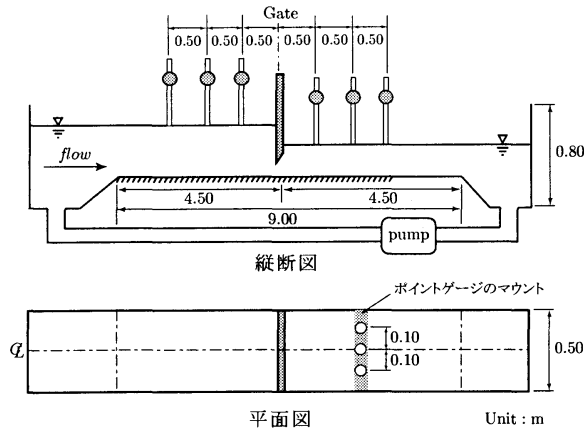

図-3 実験に利用した水槽とポイントゲージの配置図

ゲートからの流出量が精度良く評価されていることも 重要である.

Henry はゲートからの流出量を,

$$
q_{g}=C a \sqrt{2 g h_{1}}
$$

で与えている. ここに， $q_{g}$ はゲートからの単位幅当た りの流出量, $C$ は流量係数, $a$ はゲートの開口高さ, $h_{1}$ はゲート上流側の水深である. 式中の各記号は図-2に 示すとおり定義した．また，図中の $h_{0}$ はゲートの先端 が水中に浸る前の水深を意味し，本研究ではこの水深 を $h_{0}$ と定義することにした.

式 (1) を用いてゲートからの流出量を精度良く計算 するためには, 流量係数 $C$ の特性を把握している必要 がある．このための水理実験を以下のような条件と装 置を用いて行った.

実験条件は表-1 に示すように，ゲートを水中に浸す 前の水深 $h_{0}$ は $0.15 \mathrm{~m}, 0.20 \mathrm{~m}$ の 2 種類, 流れの規模 は Froude 数 $F r_{0}$ で規定してその範囲を 0.05〜0.25 と し 0.05 間隔で変化させるように, ゲートの水路床から の開口高さ $a$ は $0.01 \sim 0.13 \mathrm{~m}$ の範囲として $0.01 \mathrm{~m}$ 間 隔で変化させるように設定した.ここで，Fr $F r_{0}$ はゲー 卜を水中に浸す前の水深 $h_{0}$ に関する Froude 数である. 実験装置には，図-3 に示す，両側面ガラス張り，水 路幅 $0.50 \mathrm{~m}, 9.00 \mathrm{~m}$ の水平水路床部を有し, ポンプに より水流を発生させることが可能な水路を利用した. 利 用したゲートは，アクリル製で，幅 $0.50 \mathrm{~m}$ ，高さ 0.40 $\mathrm{m}$, 厚さ $0.02 \mathrm{~m}$, 先端部を $45^{\circ}$ にカットしたリップタ イプである. 実験の際にはこれを水路の水平水路床部 


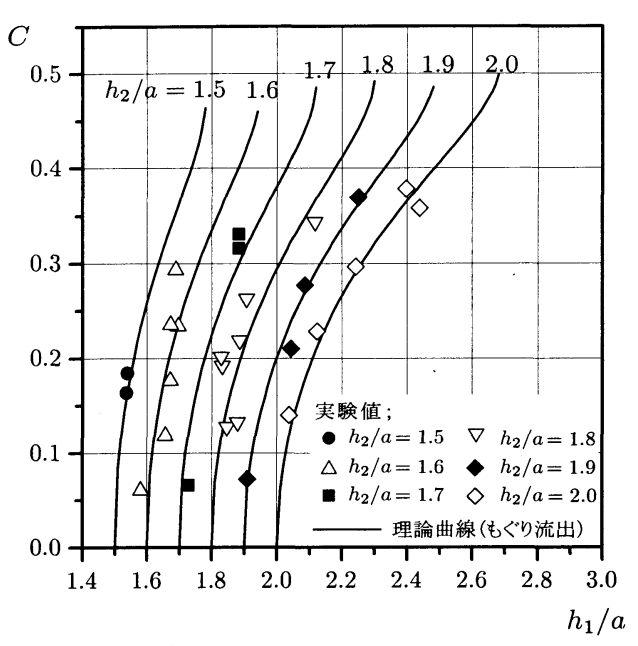

(a) もぐり流出 $h_{1} / a=1.5 \sim 2.0$

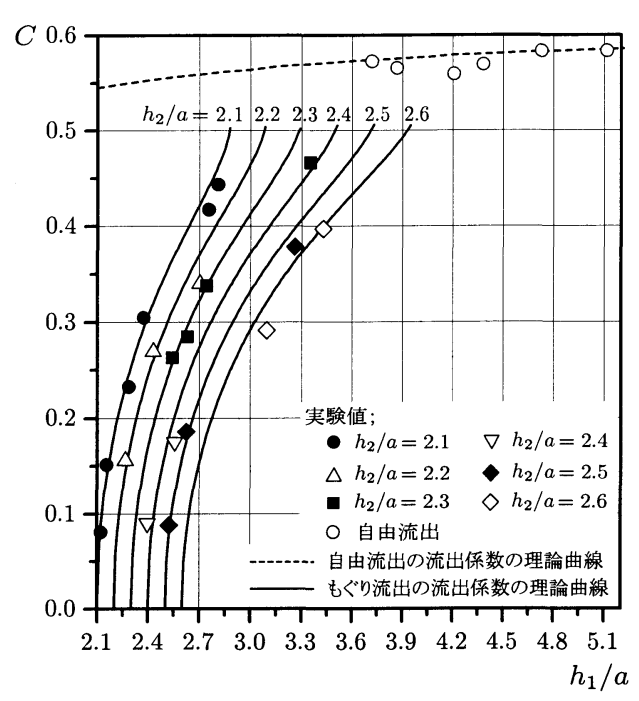

(b) 自由流出, もぐり流出 $h_{1} / a=2.1 \sim 2.6$

図-4 流量係数 $C$ の理論值と実験値の比較

の中央部に設置した. ゲートの上流側水深 $h_{1}$ と下流側 水深 $h_{2}$ の討測にはポイントゲージを用い, 図 $-\mathbf{3}$ の上段 に示すように縦断方向には $0.50 \mathrm{~m}$ 間隔で 3 箇所, 図-3 の下段に示すように横断方向には 3 本のポイントゲー ジをマウントに $0.10 \mathrm{~m}$ 間隔で設置して計測を行った. ただし, 自由流出となるケースに関しては跳水点より下 流側で計測を行ったため, 縦断方向の計測位置は図-3 に示した限りではない. そして, 上流側, 下流側でそ れぞれ 9 力所の計測值から平均值を求め, 上流側水深 $h_{1}$, 下流側水深 $h_{2}$ とした. 流量に関しては, 水流発生 用のポンプに設置されている電磁流量計を用いて計測 した.

\section{(2) 流量係数に関する Henry の理論解}

Henry は, 式 (1) の流量係数 $C$ をもぐり流出と自由 流出の場合に分けてそれぞれ理論解を求めている.

もぐり流出に関する流量係数 $C$ は, まず, 図-2 の断 面 (a)-I（ゲート上流部）と断面 (a)-II（ゲート下流の ウェイク中) で

$$
h_{1}+\frac{1}{2 g}\left(\frac{q_{g}}{h_{1}}\right)^{2}=h+\frac{1}{2 g}\left(\frac{q_{g}}{C_{c} a}\right)^{2}
$$

のようにベルヌーイの定理を適用する. そして, 損失 の大きい断面 (a)-II（ゲート下流のウェイク中）と断面 (a)-III（ある程度水面の乱れが小さくなった断面）では,

$$
\rho q^{2}\left(\frac{1}{h_{2}}-\frac{1}{C_{c} a}\right)=\frac{1}{2} \rho g\left(h^{2}-h_{2}^{2}\right)
$$

のように運動量の定理が成立する.ここに， $h_{2}$ はゲー
卜下流側の水深, $h$ は縮流断面における水深, $g$ は重力 加速度, $C_{c}$ は収縮係数である.

すなわち流量係数 $C$ はこれら 2 式を連立して,

$$
\begin{aligned}
& C_{0}^{2}\left(H_{1}-\frac{1}{H_{1}}\right)^{2}+ \\
& 2 C_{0}\left\{1+2 H_{1}\left(1-\frac{1}{H_{2}}\right)-H_{1}^{2}\right\}+ \\
& H_{1}^{2}-H_{2}^{2}=0
\end{aligned}
$$

のように求められる.ここに, $H_{1}, H_{2}, C_{0}$ はそれぞれ,

$$
\begin{gathered}
H_{1}=\frac{h_{1}}{C_{c} a} \\
H_{2}=\frac{h_{2}}{C_{c} a} \\
C_{0}=\left(\frac{C}{C_{c}}\right)^{2}
\end{gathered}
$$

である.

一方, 自由流出のときの流量係数 $C$ に関する理論解 は, 図-2 の断面 (b)-I（ゲート上流部）と断面 (b)-II (ゲートからの流出断面)に

$$
h_{1}+\frac{u_{1}^{2}}{2 g}=C_{c} a+\frac{u^{2}}{2 g}
$$

のようにベルヌーイの定理を適用して,

$$
C=\frac{C_{c}}{\sqrt{1+\frac{C_{c} a}{h_{1}}}}
$$

の形で得られる.ここに, $u_{1}$ は断面 (b)-Iにおける流 速, $u$ は断面 (b)-II における流速である. 
表-2 ゲートを緩閉する実験ケースの条件

\begin{tabular}{c|c}
\hline 水理諸量 & 設定範囲 \\
\hline Froude 数 $F r_{0}$ & $0.05 \sim 0.30,0.05$ 間隔に設定 \\
\hline 水深 $h_{0}$ & $0.15,0.20 \mathrm{~m}$ \\
\hline ゲート降下開始位置 $a_{s}$ & $h_{0}, h_{0} / 2, h_{0} / 3, h_{0} / 4$ \\
\hline ゲート降下速度 $V_{g}$ & $0.015,0.055,0.095 \mathrm{~m} / \mathrm{s}$ \\
\hline
\end{tabular}

表-3 ゲートを急閉 (自由落下) する実験ケースの条件

\begin{tabular}{c|c}
\hline 水理諸量 & 設定範囲 \\
\hline Froude 数 $F r_{0}$ & $0.05 \sim 0.30,0.05$ 間隔に設定 \\
\hline 水深 $h_{0}$ & $0.05 \sim 0.20 \mathrm{~m}, 0.05 \mathrm{~m}$ 間隔に設定 \\
\hline ゲート降下開始位置 $a_{s}$ & $h_{0}$ \\
\hline ゲート降下速度 $V_{g}$ & $0 \sim \sqrt{2 g h_{0}}$ \\
\hline
\end{tabular}

\section{(3) 本研究の実験結果と Henry の理論値との比較}

流量係数 $C$ とゲートの開口高さ $a$, ゲートの上流側 と下流側の水深 $h_{1}, h_{2}$ の関係について Henry $\left.{ }^{2}\right)$ が整理 している. 図-4 (a), (b) は流量係数 $C$ の理論解と実 験值の比較を Henry と同様の方法で整理したものであ る.これらの図は, 実線がもぐり流出の流量係数 $C$ の 理論值, 点線が自由流出の流量係数 $C$ の理論値, その 周辺のマークが理論值に対応する実験值を示している. 自由流出に関する流量係数 $C$ はゲートの上流側水深 $h_{1}$ とゲートの開口高さ $a$ の関数となるため 1 本の曲線で 表現されるが, もぐり流出に関する流量係数 $C$ はゲー 卜の上流側水哚 $h_{1}$, 下流側水哚 $h_{2}$ とゲートの開口高さ $a$ の関数となるため複数の曲線となる. なお, 流量係数 の理論值の算出にあたり, $C c$ は 0.625 とした. これら の図から, 理論值と実験值の間に多少のばらつきがあ るものの, 両者はおおむね一致していることが分かる. また, 理論值と実験値の誤差について検討したところ, 最大で $5.0 \%$ 程度であった. 以上のことから, 数値解析 を行う場合の流量係数 $C$ の算定に式 (4), (9) を適用す ることは妥当であると考えられる.

\section{4. ゲートの閉鎖に伴い発生する段波の水理} 実験

\section{（1）実験条件}

ここでは, ゲートの閉鎖に伴い発生する段波の特性 を考察するために，ゲートを自由落下に任せて降下さ せる急閉の実験ケースとモータの動力を利用して等速 度で降下させる緩閉の実験ケースの 2 つの水理実験を
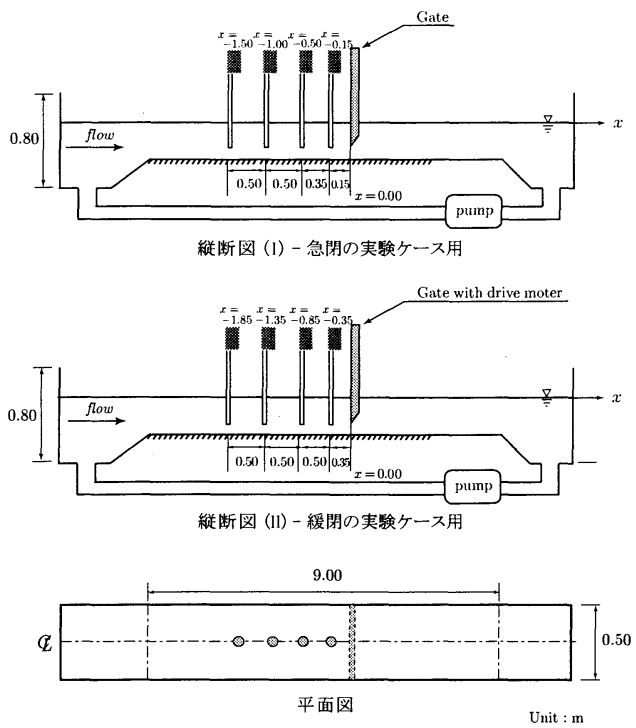

図-5 実験に利用した水路と波高計の配置図

行った.これらの実験の条件と利用した装置は次の通 りである.

まず, ゲートを緩閉する場合の実験条件は, 表-2に 示すように, 流れの規模は Froude 数で規定してその範 囲を 0.05〜0.30 として 0.05 間隔で変化させるように, ゲートを水に浸す前の水深 $h_{0}$ は $0.15,0.20 \mathrm{~m}$ の 2 ケー ス, ゲートの降下開始位置 $a_{s}$ は $h_{0}, h_{0} / 2, h_{0} / 3, h_{0} / 4$ の 4 ケース, ゲートの降下速度 $V_{g}$ は $0.015 \mathrm{~m} / \mathrm{s}$ の低 速モード, $0.055 \mathrm{~m} / \mathrm{s}$ の中速モード, $0.095 \mathrm{~m} / \mathrm{s}$ の高速 モードの 3 ケースを組み合わせた, 都合 97 ケースで ある. そして, ゲートを急閉する場合の実験ケースは, 表-3に示すように，流れの規模は緩閉の実験と同様に Froude 数で規定してその範囲を $0.05 \sim 0.30$ として 0.05 間隔で変化させるように, 水深 $h_{0}$ は $0.05 \sim 0.20 \mathrm{~m}$ の範 囲として $0.05 \mathrm{~m}$ 間隔で変化させるように設定した, 都 合 44 ケースである. なお, 実験条件に利用した Froude 数はゲートを水の中に浸す前の定常流に関する Froude 数 $F r_{0}$, ゲートの降下開始位置 $a_{s}$ は水路床から測った ゲートの開口部高さである.

実験装置は，流量係数に関する水理実験と同じ図-5 に記述の水路とゲートを用いた. 段波波高の計測には容 量式波高計を用い, 図-5に示すように急閉の実験ケー スでは上段図, 緩閉の実験ケースでは中段図に示した ように，どちらの実験でも 4 本の波高計を設置し，そ の計測時間間隔は 0.05 秒とした．ただし，ゲートの降 下速度を制御するモータの設置の都合上，急閉と緩閉 の実験ケースでは若干設置位置が異なる．また，波高 計の横断面方向の設置位置は図-5 の下段図のように水 路の横断方向の中央とした. 


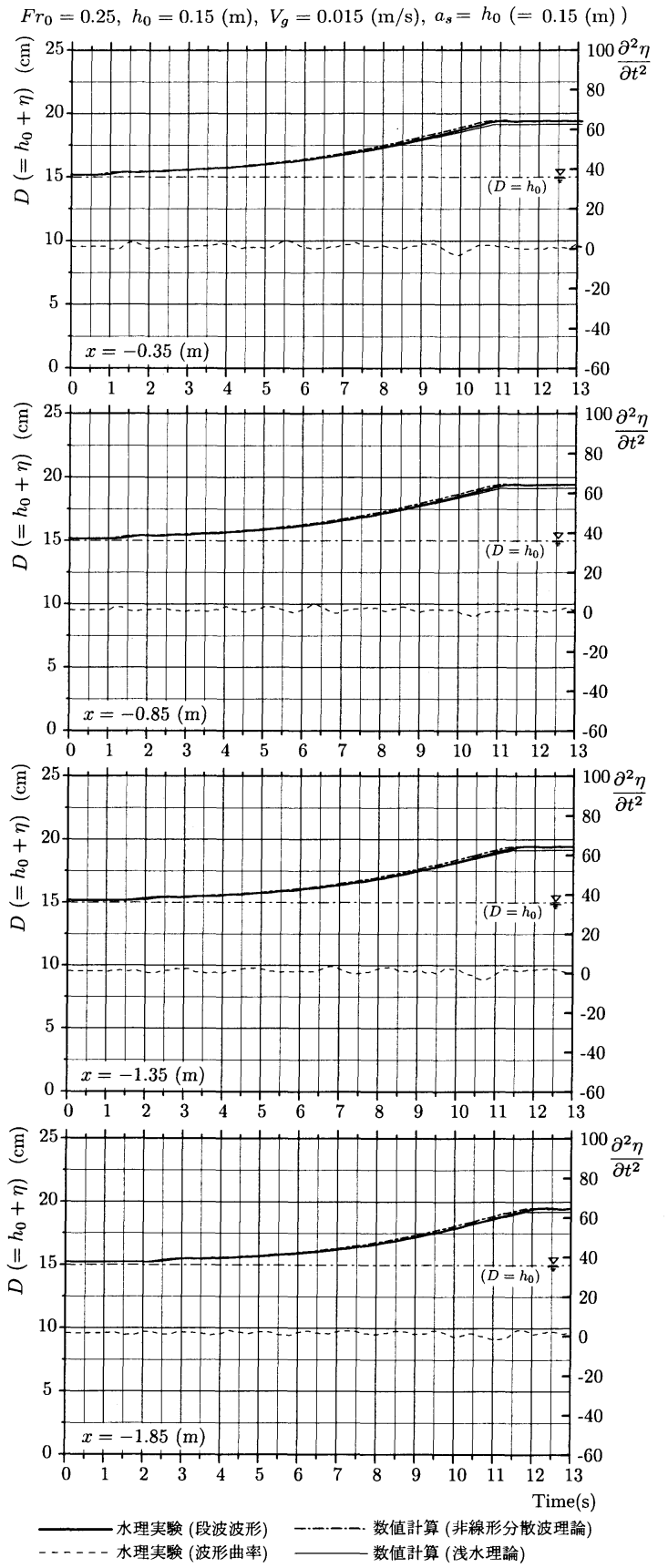

(a) ゲートを緩閉した実験ケース (低速モード)
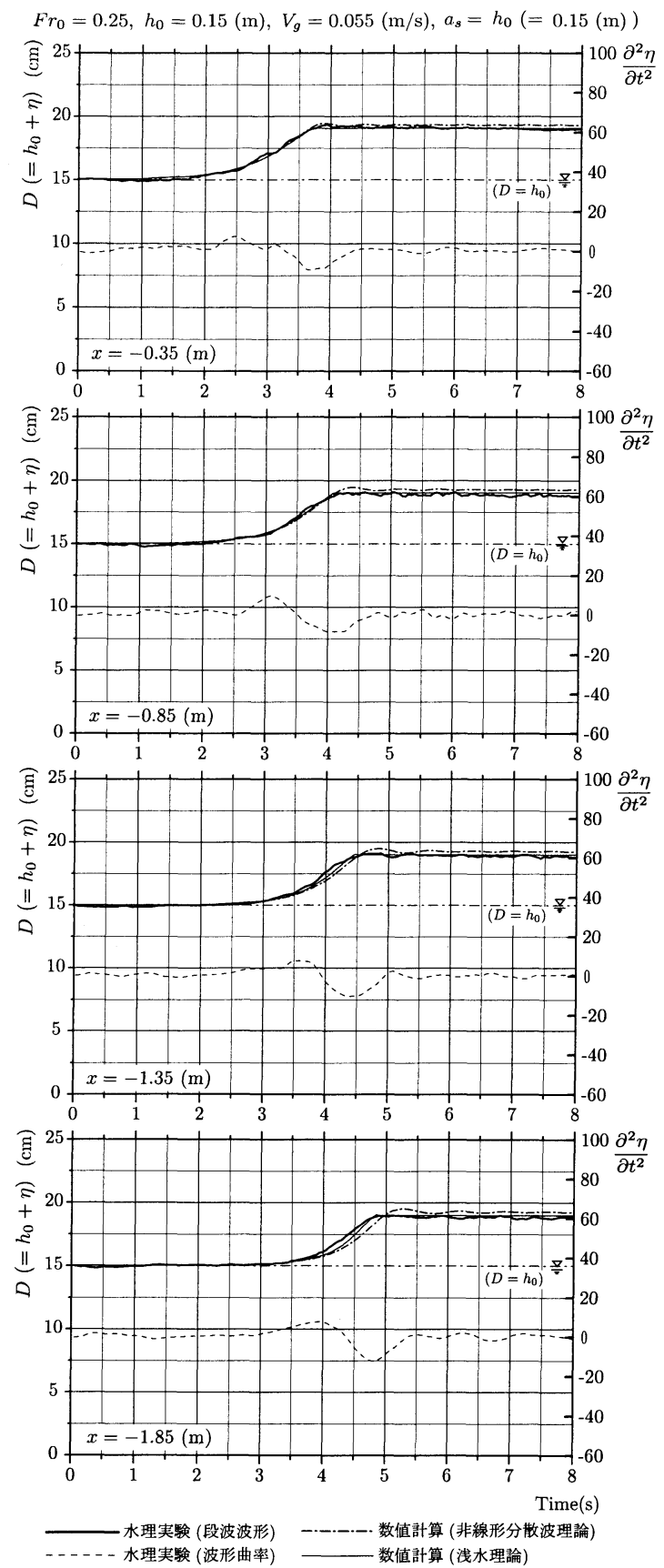

(b) ゲートを緩閉した実験ケース (中速モード)

図-6 ゲートの閉鎖に伴い発生した段波の波形 (実験值と計算值の時間波形, 実験波形の波形曲率)

（2）実験結果

表-2, 3 の条件に基づき，ゲートを緩閉した実験を 97 ケース，急閉した実験を 44 ケースの合計 141 ケー スの実験を実施した. 図-6 (a)〜 (e)にその結果の一例
を時間波形図により示す.これらの図は,いずれとも 同じ Froude 数, 水深 $h_{0}$ において, ゲートの閉鎖方法, すなわちゲート降下速度 $V_{g}$ やゲート降下開始位置 $a_{s}$ を変化させた場合に発生した段波で, 計測開始後 1 秒 
$F r_{0}=0.25, h_{0}=0.15(\mathrm{~m}), V_{g}=0.095(\mathrm{~m} / \mathrm{s}), a_{s}=h_{0}(=0.15(\mathrm{~m}))$
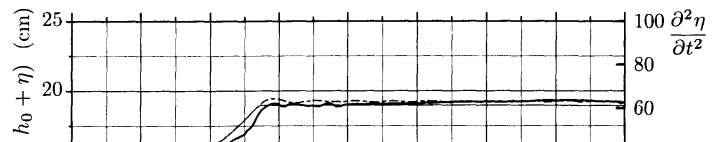

II

a
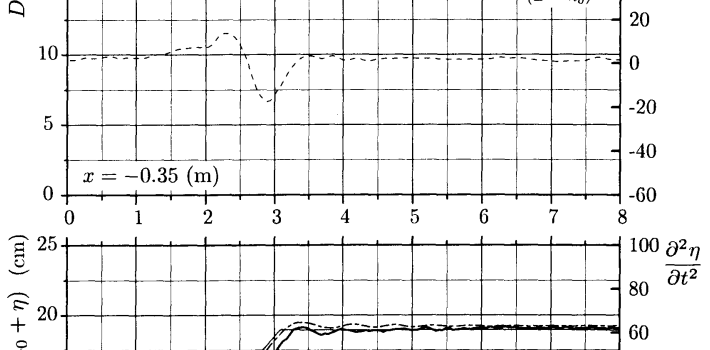

s

II
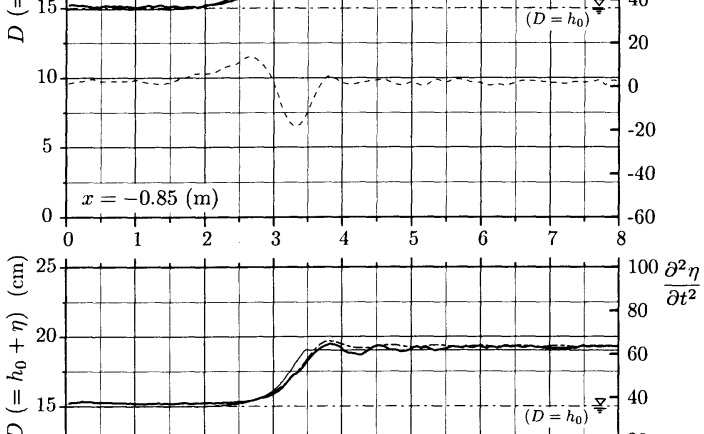

Q
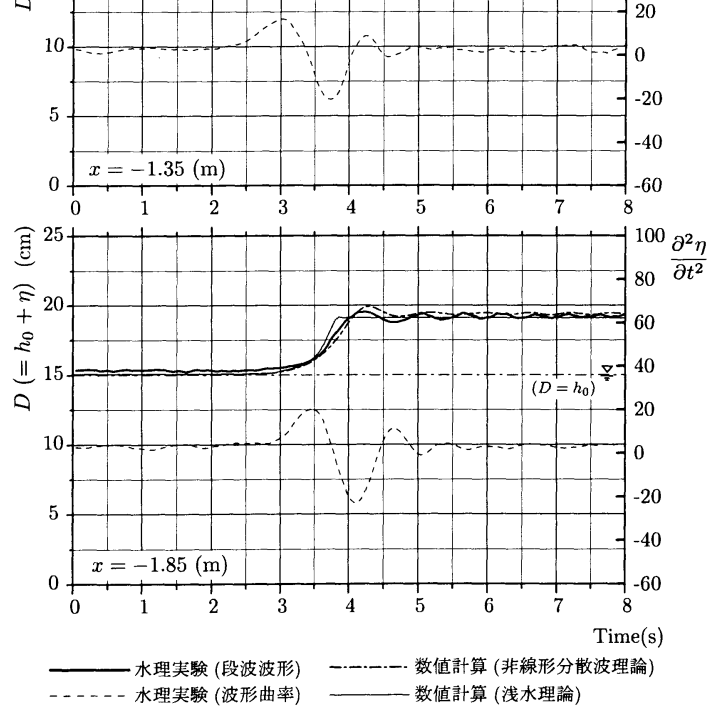

(c) ゲートを緩閉した実験ケース (高速モード I)
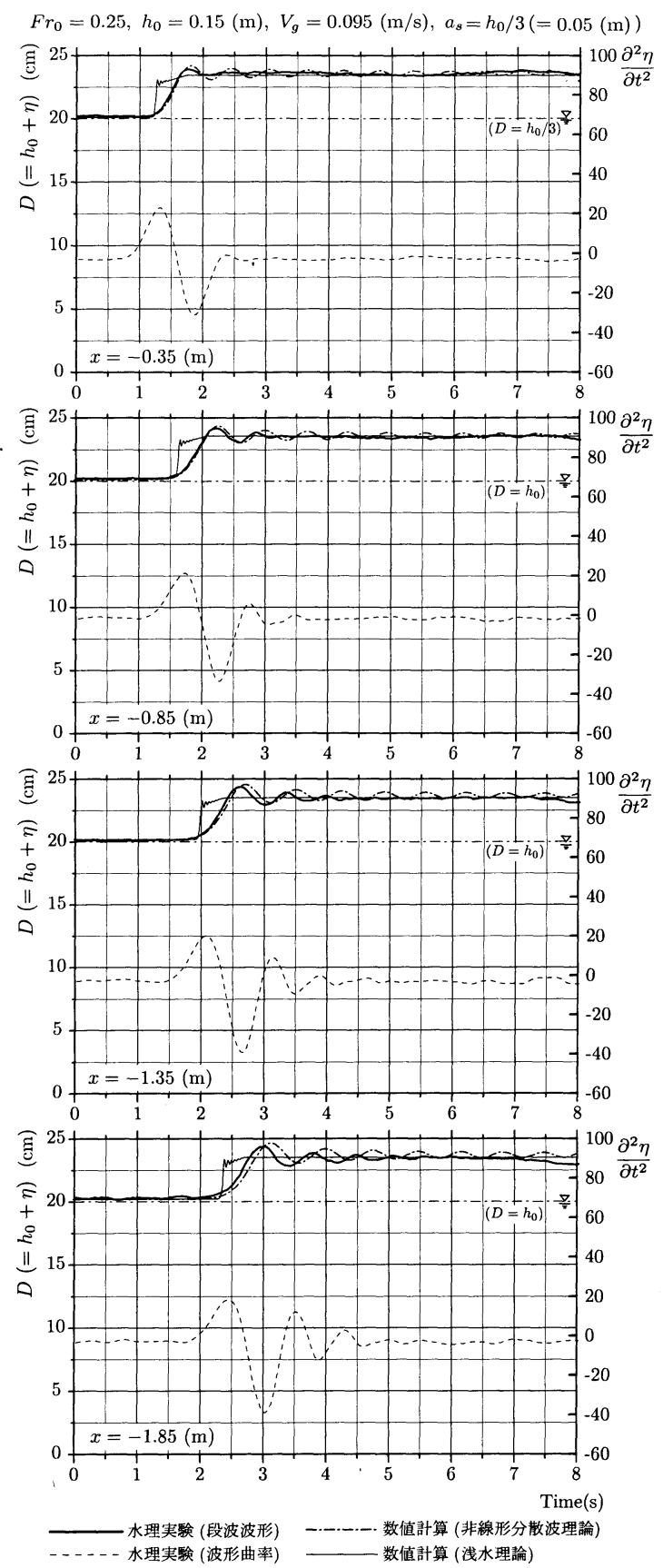

(d) ゲートを緩閉した実験ケース (高速モード II)

図-6 ゲートの閉鎖に伴い発生した段波の波形 (実験值と計算值の時間波形，実験波形の波形曲率)

になったところでゲートの閉鎖を開始した.これらの 図は縦軸を全水深 $D\left(=h_{0}+\eta\right)$ で表し, 図中の太実線 が各測定点における時間波形, 細点線がその波形の曲 率を示し, 図中の左下の数值がゲートの位置を原点と
した場合の観測点の位置を示している. また，後で詳 述するが，1点破線と細実線は数值計算の結果である. 図-6 (a) はゲートを水面から低速モードで降下させた 緩閉の場合, 同図 (b) はゲートを水面から中速モード 


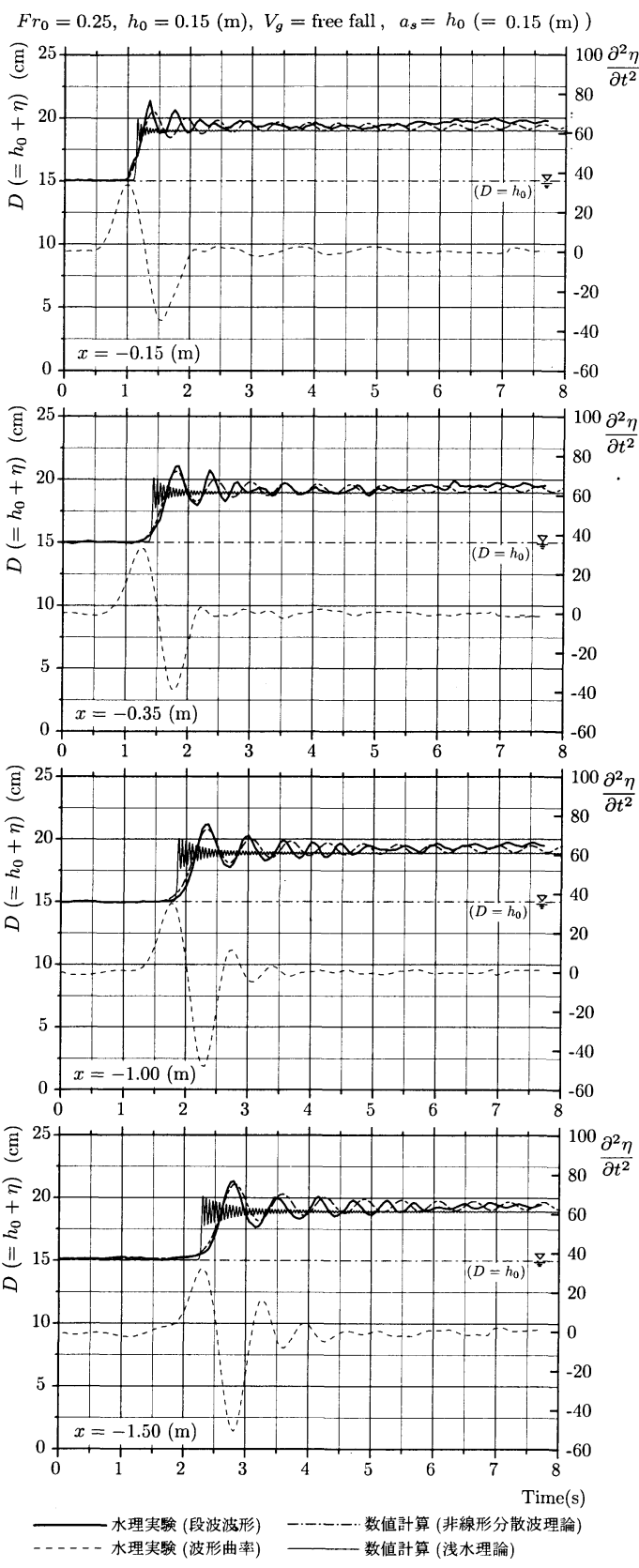

(e) ゲートを自由落下した実験ケース

図-6 ゲートの閉鎖に伴い発生した段波の波形 (実験值と計 算值の時間波形, 実験波形の波形曲率)

で降下させた緩閉の場合, 同図 (c) はゲートを水面から 高速モードで降下させた緩閉の場合, 同図 (d) はゲー トを水路床から $h_{0} / 3$ の高さから高速モードで降下させ て緩閉の場合，そして同図 (e) はゲートを水面から自 由落下させた急閉の場合に発生した段波の時間波形を 示している.



(a) ゲートを緩閉した実験ケース

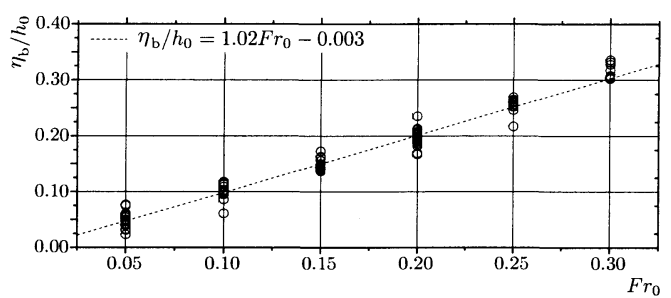

(b) ゲートを急閉した実験ケース

図-7 Froude 数と波高水深比の関係

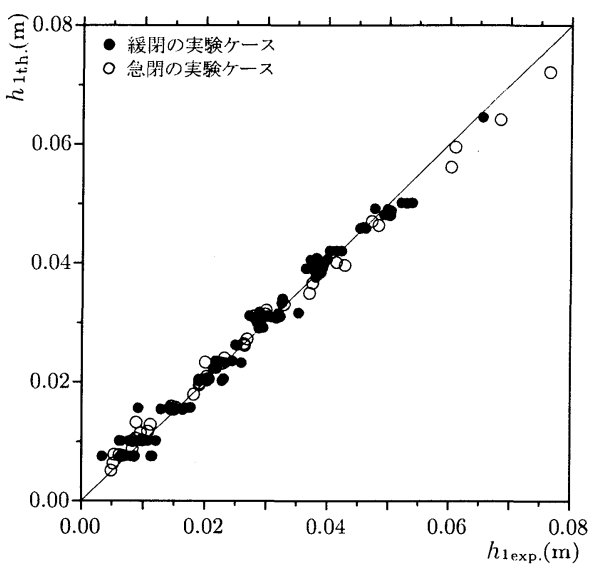

図-8 段波波高の理論値と実験值の比較

\section{(3) Froude 数と段波波高の関係}

水理実験の一例を示した図-6 (a)〜 (e) から, 波状段 波を形成しているか否かの違いはあるものの, 最終的 にはおおむね同じ段波波高に到達していることが分か る.これらのうち, 図-6 (d) では最終的な段波波高が それ以外と異なっているが，これはゲート降下開始前 のゲートの上流側の水位が他のケースと異なるためで ある.

ここでは，各実験の段波平均波高 $\eta_{b}$ を利用して，す なわち理想段波と見なして実駼結果を考察する. 図-7 (a), (b) に示すように Froude 数と段波波高の関係を調 べた.これらの図から緩閉, 急閉の実験ケースともに Froude 数が大きくなるに従って 1 次関数的に段波波高 


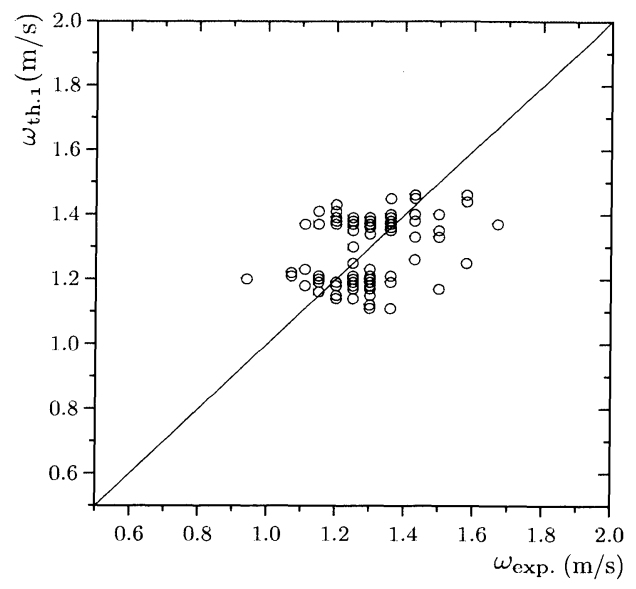

(a) 式 (10), (11) から得た理論値と実験值の比較

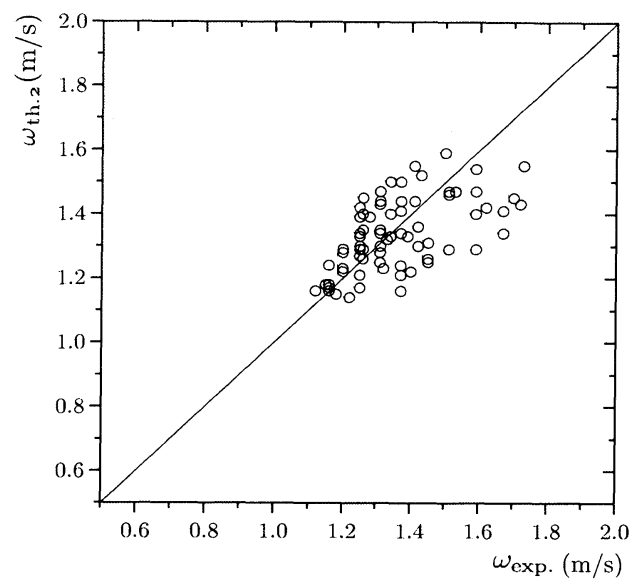

(b) 式 (12) から得た理論值と実験値の比較

図-9 ゲートを緩閉した実験ケースの段波波速の理論值と実験值の比較

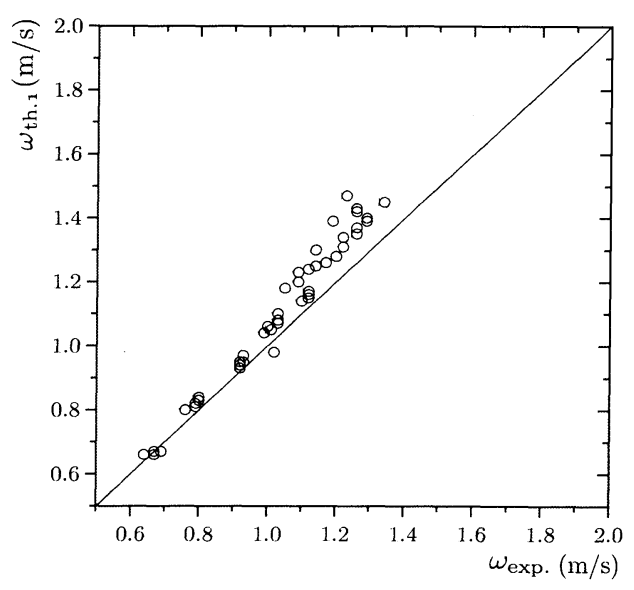

(a) 式 (10), (11) から得た理論値と実験值の比較

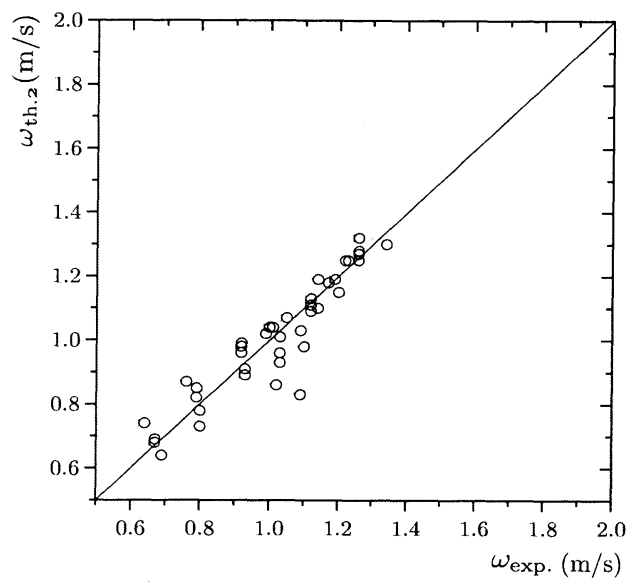

(b) 式 (12) から得た理論值と実験值の比較

図-10 ゲートを急閉した実験ケースの段波波速の理論値と実験値の比較

が大きくなっていることが分かる. しかも，両実験ケー スともに同じ Froude 数に対する波高水深比は概ね同じ 数值を示し，その勾配もほぼ同じである. なお, 緩閉の 実験ケースに関するこの関係を調べるにあたり, 表-2 で示した Froude 数 $F r_{0}$ とは異なる $F r_{1}$ を次のように 定義した. $F r_{1}$ はゲートを降下開始位置 $a_{s}$ に設定して 流れが安定した状態におけるゲート上流側水哚 $h_{1} に$ 対 する Froude 数である.

\section{（4）波速・波高の理論値と実験值の比較}

a) 実験值を理想段波と見なした場合

前項と同様に実験值に関しては平均波高 $\eta_{b}$ を利用し て理想段波と見なし，また運動量の定理から得られる理
想段波の波高と波速を理論值として両者の比較を行った.

矩形水路での理想段波の波速 $\omega_{\mathrm{th} .1}$ は, 運動量の定理 から

$$
\omega_{\text {th. } 1}=u_{1} \pm \sqrt{g h_{0}}\left\{\frac{1}{2} \frac{h_{1}}{h_{0}}\left(\frac{h_{1}}{h_{0}}+1\right)\right\}^{1 / 2}
$$

で与えられる ${ }^{31)}$. 段波の波速 $\omega_{\text {th. } 1}$ やその水哚 $h_{1}$ は， まず，この式の後半の平方根部分を 1 とおいて $\omega_{\mathrm{th} .1}$ の 第一次近似值を求め, この值と連続の式,

$$
\omega_{\text {th.1 }}=\frac{q_{1}-q_{0}}{h_{1}-h_{0}}
$$

より段波の水深 $h_{1}$ の第一次近似值を求める. ここに, $q_{0}$ は実験開始時から与えている流量, $q_{1}$ はゲート上流 
側における流量である，以下，式 (10)，(11) を収束す るまで交互に計算することで $\omega_{\mathrm{th} .1}, h_{\mathrm{th} .1}$ を得た. なお, ゲート閉鎖後のゲート上流側での流量 $q_{1}$ は 0 と考えて, この計算を行っている.

まず，図-8は式 (10)，(11) から得られた段波波高の 理論值と実験值の比較図で, 図中の○が緩閉, ○が急閉 の実験ケースを表している．緩閉，急閉のいずれの実 験ケースも理論值と実験值のズレは平均で $\pm 5 \%$ 程度で, 両者は良く一致していることがわかる.

つぎに, 式 (10), (11) を用いて段波波速についても 評価する. 実験值の段波波速 $\omega_{\text {exp. }}$ は, 設置した波高計 を波峰が通過する時間差を利用して算出した，その結 果を図-9 (a), 図-10 (a) に示す. 理論值と実験值のズ レは, 緩閉の実験ケースでは平均で $\pm 22 \%$, 急閉の実験 ケースでは平均で $\pm 6 \%$ 程度であった. 緩閉の実験ケー スでは若干ばらつきが見られるものの, 段波波速に関 しても式 (10), (11) を用いて概ね評価できる.

以上のことから, 波状性を無視して理想段波として 取り扱う範囲なら段波の波高, 波速ともに式 (10), (11) を用いてある程度評価できることが分かる.

\section{b) 段波の波状性を考慮した場合}

図-10 (a)に示すように, 急閉の実験ケースでは波速 が大きくなるに従って理論值が実験值に比べ過大に評 価される傾向があった.この原因は, 式 (10) は波状性 を無視した場合の段波に関する式で, 波状性すなわち 波の分散性による波速の減速の影響を評価できないた めであると考えられる.

ここで, 波状性が段波の波速に及ぼす影響を考察す るためにこの影響を考慮した $\mathrm{KdV}$ 式から導出される波 速の式,

$$
\omega_{\text {th. } 2}=\sqrt{g h_{0}}\left(1+\frac{3}{4} \frac{\eta_{1 \text { st. }}}{h_{0}}+\frac{1}{6} \frac{\eta_{\text {st. }}^{2}}{h_{0}} \frac{\partial^{2} \eta_{1 \text { st. }}}{\partial x^{2}}\right)
$$

から得られる值を理論值として実験值との比較をした. ここで $\eta_{1 \text { st. }}$ は段波の分散第 1 波の波高である.

これについて比較した結果が図-9 (b) と図-10 (b)で ある. 理論值と実験值のズレは, 緩閉の実験ケースが平 均で $\pm 12 \%$ 程度, 急閉の実験ケースが平均で $\pm 5 \%$ 程度 となり, 平均值で考える範囲では式 (10)を用いた場合 より若干向上している程度である. しかし, 図-10 (b) に示すように, 図-10 (a) で見られた波速が大きくなる に従い計算值が実験值に比べて過大に評価される傾向 が緩和されていることが分かる. 一方, 図-9 (a) と (b) では急閉の実験ケースのそれと比べると, 二者の差異 は小さい. すなわち, 式(12) の括弧内の第 3 項の波の 分散性による補正の効果が, ゲート閉鎖の直後から急 峻な段波面を形成して波形曲率が大きくなる急閉の実 験ケースでは大きく, 緩閉の実験ケースでは小さく作 用したためと考えられる.これらのことは, 形成され
た段波の形状によってはその波状性を考慮した解析が 必要であることを示唆するものである.

\section{（5）段波の波状性に関する考察}

図-6 (a)〜(e) に示したように, 同じ Froude 数 $F r_{0}$, 水深 $h_{0}$ であるにも関わらずゲートの閉鎖方法 (ゲート の降下速度や降下開始位置) の違いによって, ゲートの 閉鎖直後から著しい波状段波を形成する場合と単純に 水位上昇するだけにとどまる場合のようにその形態は 大きく異なることが見て取れる．このことは，例示し た実験ケースのうち, ゲートの降下開始位置 $a_{s}$ だけが 異なる図-6 (c), (d) を比較すると, 各観測点での波状 段波への変形過程が顕著に異なることからも良く分か る. そのうえ，前項に示したように段波の波状性はそ の波速に対しても少なからず影響を及ぼしている.

ここでは, ゲートの閉鎖に伴い発生する段波の波状 性の特性をつぎのとおり調べた. 段波波形の波状性の 規模を考察するうえで適当なパラメータである波高増 幅率 $\eta_{\max } / \eta_{b}$ を導入して, Froude 数, 波高水深比と波 高増幅率の関係を整理した。これらの関係を整理する にあたり，ゲートを急閉した実験ケース，緩閉した実 験ケースに関しては波状段波となったケース，そうで ないケースの 3 つに分類して, 図-11 (a), (b) に示す ように整理した.ただし，緩閉した実験ケースにおけ る波状性の分類は, ゲートから $1.85 \mathrm{~m}$ の区間内に設置 された 4 本の波高計で観測されたいずれかの時間波形 の波頭が少なくとも一組の波峰と波谷を形成して明ら かに波状性を示したか否かで分類した.

本実験とは実験方法が異なるために単純に比較する ことはできないが, Bazin ${ }^{3)}$, Keulegan \& Patterson ${ }^{6)}$, Tsuji et al. ${ }^{27)}$ は，それぞれ波状段波の波高増幅率は 1.5 以下であることを理論的あるいは実験的に示している. また, Keulegan \& Patterson ${ }^{6)}$, Chester ${ }^{8)}$, Johnson ${ }^{9)}$, 松富 ${ }^{17)}$ は段波の波状性の判定パラメータに波高水深比 を用い, これが $0.61 〜 0.79$ 程度以下だと波状段波にな るとしている.

これに対して, 本研究のゲートを急閉した実験ケース に関してはどのケースにおいても発生した段波はゲー 卜閉鎖直後から強い波状性を示し，その波高増幅率は 最大で 1.7 を超えることがあった. そして, この時, 波 高増幅率は Froude 数や波高水深比に従属的な傾向を 示し, その波高水深比は最大で 0.35 程度であった. 一 方，ゲートを緩閉した実験ケースに関しては発生した 段波の波高増幅率は最大では 1.3 にまで至ることがあっ た. ただし, ゲートを急閉した実験ケースとは異なり， Froude 数や波高水深比と波高増幅率の関係を考えた場 合にそれらの間に明確な関係を認めることができなかっ た.この時, 波高水深比は急閉の実験ケースと同様に 


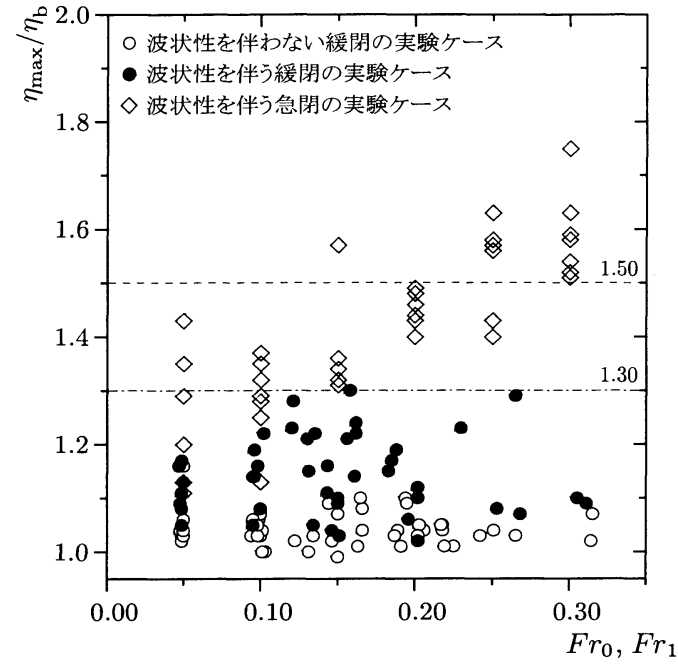

(a) Froude 数と波高増幅率の関係

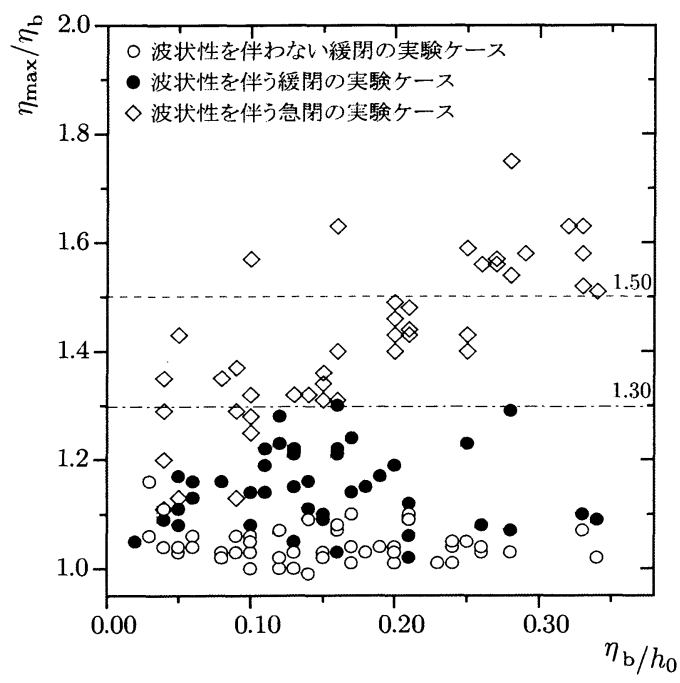

(b) 波高水深比と波高増幅率の関係

図-11 Froude 数・波高水深比と波高増幅率の関係. (既往の 研究6),8，9),17)では，段波の波状性の判定のパラメータに 波高水深比を用い, これが $0.61 \sim 0.79$ 程度以下だと波状段 波になるとしている. 一方, 本実験の緩閉のケースでは, 上 図 (a), (b)に示すとおり, Froude 数や波高水深比と波高増 幅率の間に明瞭な関係を認められず，これらとは無関係に 波状性を伴う段波が発生した.)

最大で 0.35 程度であった.

前述のようにその波速にも少なからず影響を及ぼす うえ, 緩閉でしかも短い区間内にもかからわず波高増 幅率が 1.3 程度までに至ることから, この種の段波を取 り扱う場合には波状性を考慮したうえで取り扱うこと が重要であることが分かる.

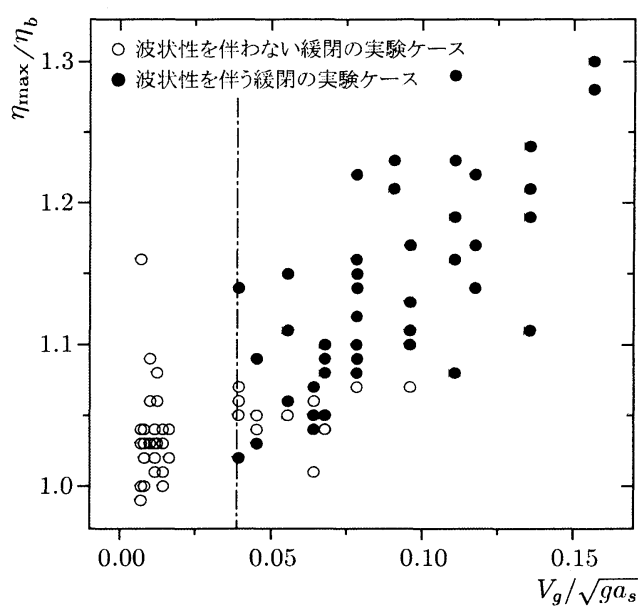

図-12 ゲートを緩閉した場合の波状段波の発生条件.（パラ メータ $V_{g} / \sqrt{g a_{s}}$ を導入することで, 初期段階から著しい 波状段波を生成させるゲートの閉鎖方法を把握することが できる．ここで， $a_{s}$ はゲート降下開始位置， $V_{g}$ はゲート降 下速度である.)

\section{（6）波状段波の発生条件}

既往の研究では段波の波状性の判定のパラメータに 波高水深比を用い, これが $0.61 〜 0.79$ 程度以下だと波 状段波になることを示している. 一方, 先に示したと おり本研究の水理実験では, 図-11 (b) に示すように, 急閉, 緩閉の実験ケースのすべてのケースがこの条件 内に含まれているうえ，波状性を伴う場合とそうでな い場合の両方が混在している. ゲートの閉鎖方法によ る影響が及ばないゲートから遠く離れた場所において は, 既往研究の波状段波の発生条件をそのまま適用で きるものと考えられる. しかし，ゲートの閉鎖に伴い 発生した段波がゲート近傍において波状性を伴うか否 かを判定する際にこれをそのまま適用することが適切 でなはないことは明らかである. 従って, 本研究で対 象とするような段波の波状性を判定するのに適した新 たなパラメータを考える必要がある.

本研究で対象とするような波状段波の発生条件を考 えるためには，ゲート閉鎖後の段波面の形成に支配的 な影響を与えるゲートの閉鎖方法をそのパラメータと して導入する必要がある．すなわち，ゲートの閉鎖方 法に関するパラメータは, ゲートからの流出量の時間 的な変化率の大きさを評価し得るような $V_{g} / \sqrt{g a_{s}}$ とし た. そして，緩閉の実験ケースにおけるこのパラメー タと波高増幅率の関係について次の通り調べた.

その結果は図-12 に示すとおりである.この図から， ゲートを緩閉したときにそれの閉鎖後の早い段階から 波状性の強い段波が発生するか否かの境界を把握する ことができ，その境界值は $V_{g} / \sqrt{g a_{s}}$ が 0.04 程度である ことが分かる．ゲート閉鎖後の早い段階から波状性の 
強い段波が発生するのは, $V_{g} / \sqrt{g a_{s}}$ が大きくなるゲー 卜の降下速度 $V_{g}$ が速く, 降下開始位置 $a_{s}$ が低い, すな わちゲートからの流出量に関する時間的な変化率が急 激に変化してゲートの閉鎖と同時に急峻な段波面が形 成された場合であることが理解できる。ここで，ゲー 卜閉鎖後の早い段階とは, 前項に示した波高計の設置 区間の $1.85 \mathrm{~m}$ において段波の波頭が一組の波峰と波谷 を有する波状段波に変形したか否かを基準として考え ている.

\section{5. 数値解析}

\section{(1) 支配方程式}

段波が発生して間もない段階ではその段波面の勾配 が緩やかな場合でも，伝播するに従い非線形の効果に より段波面の勾配は次第に急峻になる。 そして, 水粒 子の鉛直方向加速度が卓越するために波数分散効果が 顕著に作用するようになり，やがては波状段波へと遷 移していく．その波状段波は終局的には孤立波などの 保存波に至るが, それまでは伝播とともに波高増幅す る. このことは, 本研究において行った水理実験の結 果からも分かる.これらの段波の変形過程は, 非線形 効果と分散効果の相互作用 ${ }^{32}$ によるものであると考え られる.

一般に河道の流況は浅水理論式によって計算される ことが多い．この理論式では非線形効果が含まれるの みのため, 前述した一連の段波の変形過程を表現でき ないだけでなく，段波面の勾配が急峻となった場合で は波形の前傾化が極端に進むため，その計算は数值的 なギブス振動を発生して不安定になりやすい. 段波の 最大波高や変形過程を的確に表現するためには分散性 を考慮した浅水理論式，すなわち非線形分散波理論式 を支配方程式とする必要があり，これまでに Peregrine の式 ${ }^{12)}$, 後藤の式 ${ }^{14)}$, Madsen-Sørensen の式 ${ }^{33)}$, Beji-


いる. 岩瀬ら ${ }^{35)}$ は, これらの式およびそれらの断面積 分型の式のそれぞれに対して, 線形分散関係と各式の 孤立波の第 1 次近似解を求めて $\mathrm{KdV}$ 式の孤立波解との 比較から各式の特性について考察した．その結果, 線 形分散関係がある程度まで良好なうえ孤立波の第 1 次 近似解が $\mathrm{KdV}$ 式の孤立波解にほぼ一致する断面積分型 の Peregrineの式と, 線形分散関係が高波数まで一致す るうえ孤立波の第 1 次近似解が $\mathrm{KdV}$ 式の孤立波解にほ ぼ一致する Madsen-Sørensen の式が適切であると結論 している. 本研究が対象とするような波状段波の分散 素波を孤立波と考えれば，孤立波解に関する特性が重 要となる. 従って, 本研究では, 以下に示す断面積分
型の Peregrine の式を支配方程式とすることにした.

$$
\begin{gathered}
\frac{\partial \eta}{\partial t}+\frac{\partial q}{\partial x}=0 \\
\frac{\partial q}{\partial t}+\frac{\partial}{\partial x}\left(\frac{q^{2}}{D}\right)+g D \frac{\partial \eta}{\partial x}=\frac{h^{2}}{3} \frac{\partial^{3} q}{\partial t \partial x^{2}}
\end{gathered}
$$

ここに, $\eta$ は水位, $t$ は時間座標, $q$ は単位幅当たりの 流量, $x$ は空間座標, $h$ は静水深である. なお, 浅水理 論式は式 (14) の右辺を 0 とおいた,

$$
\frac{\partial q}{\partial t}+\frac{\partial}{\partial x}\left(\frac{q^{2}}{D}\right)+g D \frac{\partial \eta}{\partial x}=0
$$

である.

\section{(2) 数值解析法}

\section{a) 計算方法}

本研究では, 非線形分散波理論式の差分スキームとし て最適であると考えられる 2 段階混合差分法36),37),35) を適用した.この差分スキームは, 同じ時間ステップ の值を Explicit スキームと Implicit スキームに分けて 未知量を求めるものである. まず, 1 段目で連続の式と 運動方程式の局所項・圧力項すなわち線形長波理論の式 に関して Explicit スキームである Staggered Leap-flog 法を用いて流量の中間值 $q^{*}$ を求める. そして, 2 段目 では移流項・分散項に関して Implicit スキームである $\mathrm{ADI}$ 法を用いて流量の最終值を求める. 浅水理論式の 数值計算では, 差分スキームに起因する負の数值拡散 を防ぎ, 安定に計算する目的で移流項を風上差分で解 く方法が一般的である. 一方, 非線形分散波理論式に 対してこのスキームを適用した場合, 現実の物理現象 と同じように非線形効果と分散効果のバランスを維持 した計算を行うことになるため, 中央差分を用いても 安定に計算できる. そのうえ, 移流項も 2 次精度なこ とと, いずれの項も時間的にも空間的にも対称形の中 央差分となるから風上差分を用いた場合よりも精度良 く計算でき, 波高の減衰を抑制することができるとい う特徴がある. 以下にその差分式を示す.

$$
\begin{gathered}
\frac{1}{\Delta t}\left[\eta_{j}^{n+1 / 2}-\eta_{j}^{n-1 / 2}\right]+ \\
\frac{1}{\Delta x}\left[q_{j+1 / 2}^{n}-q_{j-1 / 2}^{n}\right]=0 \\
\frac{1}{\Delta t}\left[q_{j+1 / 2}^{*}-q_{j+1 / 2}^{n}\right]+ \\
\frac{g D}{\Delta x}\left[\eta_{j+1}^{n+1 / 2}-\eta_{j}^{n+1 / 2}\right]=0 \\
\frac{1}{\Delta t}\left[q_{j+1 / 2}^{n+1}-q_{j+1 / 2}^{*}\right] \\
+\frac{1}{4 \Delta x}\left[\left(\frac{q}{D}\right)_{j+3 / 2}^{n} q_{j+3 / 2}^{n+1}-\left(\frac{q}{D}\right)_{j-1 / 2}^{n} q_{j-1 / 2}^{n+1}\right]
\end{gathered}
$$




$$
\begin{gathered}
+\frac{1}{4 \Delta x}\left[\left(\frac{q}{D}\right)_{j+3 / 2}^{n} q_{j+3 / 2}^{n}-\left(\frac{q}{D}\right)_{j-1 / 2}^{n} q_{j-1 / 2}^{n}\right] \\
=\frac{h^{3}}{3 \Delta t \Delta x^{2}}\left[q_{+}^{* *}-q_{-}^{* *}\right] \\
q_{+}^{* *}=\left[q_{j-1 / 2}^{n+1}-2 q_{j+1 / 2}^{n+1}+q_{j+3 / 2}^{n+1}\right] \\
q_{-}^{* *}=\left[q_{j-1 / 2}^{n}-2 q_{j+1 / 2}^{n}+q_{j+3 / 2}^{n}\right]
\end{gathered}
$$

ここに, $\Delta t$ は時間格子長, $\Delta x$ は空間格子長, $n$ は時 間格子番号, $j$ は空間格子番号を表す.

また, 式 (15) の浅水理論式の差分スキームには Staggered Leap-flog 法を適用し, 移流項に関しては風上差 分を用いた.

\section{b) 初期条件および境界条件}

計算の初期条件には，定常の河川流を模擬するため に全部の計算格子に対して上流から下流に向かう単位 幅当たりの流量 $q_{\mathrm{rv}}$ を与えた.

境界条件には, 時間ステップが更新されるごとに数 值水槽の上流端に単位幅当たりの流量 $q_{\mathrm{rv}}$ を与えた. ま た, スルースゲートは数值水槽の下流端に設置されて おり計算開始 1.0 秒後に閉鎖が開始されるものとして, 式 (1) でゲートからの流出量 $q_{g}$ を与えた. ただし, 式 (1) の流出係数 $C$ の式 (4), (9) は, ゲートの開口高さ が大きく, ゲート上流側水哚 $h_{1}$ とゲート下流側水深 $h_{2}$ の差が小さい場合では流量係数 $C$ が 0 に漸近するため, これらの式を適用できない. 本研究ではこの問題に対 処するために, $a(t)=0.35 h_{0}$ を闇值として,$a(t)$ がこ れより小さい場合には式 (1)を用い, $a(t)$ がこれより大 きい場合には,

$$
q_{g}=\tanh \left(\frac{a(t)}{V_{g} g h_{1}}\right) q_{\mathrm{rv}}
$$

という式でゲートからの流出量を計算した. ここに, $a(t)$ は時間ステップごとのゲートの開口高さである. なお, 計算するにあたっては式(1)と (21)の 2 式にそれぞれ重 みをつけて滑らかに 2 式を接続できるように計算した.

数值計算は, 両理論式ともに空間格子間隔 $\Delta x=$ $0.02 \mathrm{~m}$, 時間格子間隔 $\Delta t=0.005$ 秒と設定して行った.

\section{（3）水理実験と数値計算結果の比較}

ここでは, 図-6 (a)〜 (e) に示す実験值と 2 つの数值 解析モデルの計算值の比較を行う. 図中の一点破線と 細実線がそれぞれ非線形分散波理論式, 浅水理論式を 用いて計算した結果である. ゲート降下速度 $V_{g}$ が遅い 図-6 (a), (b) のような実験ケースは, 両式ともによく 実験值を再現している. また，ゲート降下速度 $V_{g}$ が速 い図-6 (c), (d)や, 図-6 (e) のような伝播に従って波 状段波へ発達するような実験ケースでは, 非線形分散
波理論式を基礎式とした数值解析モデルが浅水理論式 のそれに比べ波速や波高を適切に再現した.

浅水理論式の計算は, ゲートの閉鎖直後から段波面 が急峻な場合や伝播に従い段波面が次第に急峻になっ てくると数值的なギブス振動を発生し, 数值計算は不 安定となった。これは, 現実の波動現象は非線形性に よる波速の増大効果, すなわち波形の前傾化と分散性 による波速の減速効果の両者が相互に作用してバラン スを保っていることに対し, 浅水理論式では分散性が 考慮されていないために段波波形の前傾化だけが進み, 数值的なギブス現象を導く計算結果となったためと考 えられる. また, この前傾化により, 浅水理論式の計 算波速は非線形分散波理論式のそれに比べて過大に評 価された。

一方, 非線形分散波理論式の計算では，いずれのケー スも精度良く再現することができるうえ, 波状段波と なるようなケースに関しても第 2 波までなら精度良く 再現できた. したがって, 本研究で対象とするような 波状段波は非線形分散波理論式を用いることで適切に 計算できる可能性が高いと考えられる. また, 数值計 算は安定に行うことができた.

\section{(4) 理論式の違いによる変形過程の差異に関する検討}

本研究の水理実験で利用した水路は水平床部の全長 が $9 \mathrm{~m}$ と短いため, 水理実験ではゲートの閉鎖に伴い 発生する段波の特性の一部を明らかにしたに過ぎない. ここでは, 数值解析モデルを用いて, ゲートの閉鎖方 法の違いが伝播に伴う段波の変形過程や終局的な波形 の波高などに及ぼす影響に関する数值実験を行い，そ れらについて考察する.

まず, 理論式の違いによる伝播に伴う段波の変形過程 の差異を比較することを目的とした数值実験を行った. この数值実験の初期条件は図-6 (b) と同じ $F r_{0}=0.25$, $h_{0}=0.15 \mathrm{~m}, \quad V_{g}=0.055 \mathrm{~m} / \mathrm{s}, \quad a_{s}=h_{0}(=0.15 \mathrm{~m})$ と し, $80 \mathrm{~m}$ の数值水槽を仮想してここに段波を伝播させ ることにした.

図-13にこの数值実験の結果を示す．この図は空間 波形図で, 段波の伝播に伴う変形過程が理論式により 異なることを示している. $x / h_{0}=60$ 程度までは波形 が多少異なるものの, 波速に関してはどちらの理論式 の計算結果も同様であった. そして, その後, 次第に 波形, 波速ともに差異が大きくなった.

水理実験では $x / h_{0}=15$ 程度までの観測を行ったが, この実験ケースでは観測範囲において波状段波への変 形を確認することができなかった. 数值計算の結果に おいても，その範囲では波状段波になっておらず，この 計算結果は実験の傾向を良く再現していると考えられ る. しかし, 数値計算の結果では $x / h_{0}=50$ を越える 




(a) 非線形分散波理論式（分散性を考慮した浅水理論式）の計算結果

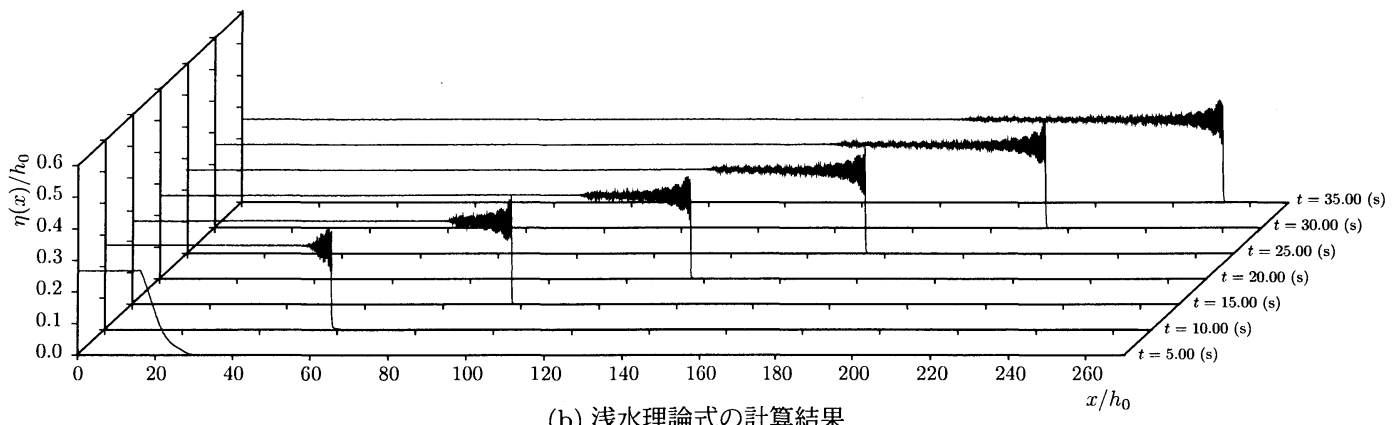

(b) 浅水理論式の計算結果

図-13 ゲートの閉鎖に伴い発生した段波を長距離伝播させる数值実験の結果.（図-6 (b) の実験条件である, $F r_{0}=0.25, h_{0}=0.15$ $\mathrm{m}, V_{g}=0.055 \mathrm{~m} / \mathrm{s}, a_{s}=h_{0}(=0.15 \mathrm{~m})$ を初期条件とした数值実験の結果. 非線形分散波理論の計算結果では, $x / h_{0}=50$ を越 えるあたりから明暸な波状段波を形成し，その後，波形や波高が一定となる終局的な波形に遷移する結果となった。一方，浅水理論 式を用いた計算では，伝播に従い段波波形の前傾化だけが進み，数值的なギブス振動を導く計算結果となった.）

あたりから明瞭な波状段波を形成し, その後, 分散性 による段波の波形や波高の著しい変形が完了して安定 した状態となり伝播する結果となった. 以後, この変 形完了後の安定した状態を終局状態と定義して用いる.

ゲートの閉鎖直後から急峻な段波面を形成するよう な実験ケースでは波状段波が確認されたことや，非線 形分散波理論を基礎式とした数值計算の結果ではこの ような実験ケースの波速や最大波高を適切に再現でき たことなどを考え合わせると，この終局的な波形への 遷移に関する計算結果は妥当であると考えられる.

\section{（5）段波の時間的な変形過程に関する数値実験}

a) ゲートの閉鎖方法の違いが変形過程に及ぼす影響 前項までに非線形分散波理論式を用いることで, ゲー トの閉鎖に伴い発生した段波を適切に計算できること を示した. ここでは, 非線形分散波理論式を基礎式と した数值解析モデルを用いた数值実験により, 段波波 形の時間的な変形過程に着目した考察を行った.

まず，ゲートの閉鎖方法の違いが段波の変形過程に 及ぼす影響について考察した。図-12 に整理したとお り,ゲートの閉鎖に伴い発生した段波の波状性は, ゲー トの閉鎖方法の影響を受ける。しかし，水理実験で明
らかになったのは $x / h_{0}=15$ 程度までの限定された範 囲における性質である，そこで，これに関する全体的 な性質を把握するために，図-6 (a)〜 (e) に示した実験 条件を初期条件として段波を長距離伝播させる数值実 験を行った.

図-14 は前述の初期条件で $80 \mathrm{~m}$ の数值水槽を 60 秒 間伝播させた結果で, 各実験ケースの計算結果の分散第 1 波の時々刻々の波峰を連ねたものである. 図中縦軸の $\eta_{\max }(t)$ は数值計算の時間ステップ毎の分散第 1 波波高 の最大值である．ゲートからの流出量の時間的変化率 が小さい図-6 (a) のような場合では, 一度, 一定波高 となり伝播していくものの, やがて再増幅を開始して 他のケースと同じ波高に至った．逆にゲートからの流 出量の時間的な変化率が大きいケースでは, ゲートの 閉鎖直後から急速に波高を高めていき，その後，早い 段階で一定波高となった。これは，分散性による著し い波高増幅を完了して終局的な波形に遷移したものと 推測できる．これらの数值実験から，ゲートの閉鎖方 法によって変形過程が異なるものの, いずれの操作方 法に依っても最終的には同一波高まで波高を增幅して, 終局的な波形に遷移することが分かった，なお，図中 の (d) に関する終局状態の波高が他の 4 ケースと異な 


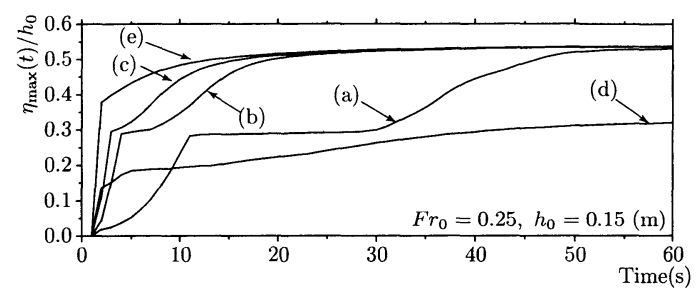

(a) $; V_{g}=0.015(\mathrm{~m} / \mathrm{s}), a_{s}=0.15(\mathrm{~m})$ (b) $; V_{g}=0.055(\mathrm{~m} / \mathrm{s}), a_{s}=0.15(\mathrm{~m})$ (c) $; V_{g}=0.095(\mathrm{~m} / \mathrm{s}), a_{s}=0.15(\mathrm{~m})$

(d) $; V_{g}=0.095(\mathrm{~m} / \mathrm{s}), a_{s}=0.05(\mathrm{~m})$

(e) $; V_{g}=$ free fall,$a_{s}=0.15(\mathrm{~m})$

図-14 ゲートの閉鎖方法の違いが段波の変形過程に及ぼす 影響

るのは，このケースだけゲート降下開始位置が異なり ゲート上流側水哚 $h_{1}$ が他のケースより哚くゲートの上 流側の Froude 数が小さかっためである.これは後述の 図-17により説明できるものと考えられる．また，こ れらの実験条件の範囲においては，水槽終端に段波が 到達することによる反射波が発生しないことを確認し たうえで数值実験を行っている.

b）流れの強さが段波波形の変形過程に及ほす影響 つぎに, 流れの強さが段波波形の変形過程に及ぼす 影響を考察することを目的に，ゲートを水に浸す前の 水深 $h_{0}$ を $0.15 \mathrm{~m}$ とゲートの降下速度 $V_{g}$ を $0.095 \mathrm{~m} / \mathrm{s}$, ゲートの降下開始位置 $a_{s}$ を $0.15 \mathrm{~m}$ に固定し, Froude 数を $0.05 \sim 1.10$ まで 0.05 間隔で変化させて長距離伝播 させる数值実験を行った.

その結果が図-15 で, Froude 数毎の分散第 1 波の最 大波高の時間的変化を示した図である.いずれの条件 においてもある段階から一定の波高を示していること から，図-14で得られた知見と同様に段波は安定的な 終局状態に遷移していると推測できる.

\section{c) 計算結果で見られた波高減衰に関する考察}

前項 b) で実施した数值実験では, Froude 数が 0.65 を超えるケースで分散第 1 波の波高が伝播に伴い明ら かに減衰していることが図-15 から分かる. しかも，こ のような波高の減衰量は Froude 数が大きい実験ケース であるほど大きくなっていることが見て取れる.

この現象は, 波と流れの共存場では波と流れの相互 作用によりエネルギー輸送速度が変化するために流れ を遡る波の波高は変化するという知見 ${ }^{38)}$ から説明でき るものと考えられる. 佐藤 ${ }^{39)}$ はこれに関してさらに踏 み込んだ議論を展開し，流速の鉛直方向分布や水面勾 配や乱れが波高減衰率に寄与することを指摘している. 本研究で用いた基礎式では流速分布や乱れの影響を考 慮していないが，水面勾配や断面平均流速の変化の影 響は含んでいる．従って，この数值実験で見られた波 高減衰は，流れを遡る段波の波高減衰を評価している と考えられる.この知見に基づくと，本実験の Froude

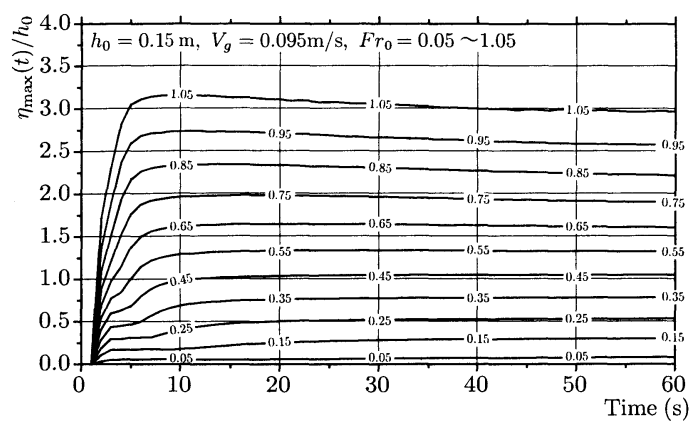

図-15 流れの強さが段波の変形過程に及ぼす影響

数が小さいケースでは波高一定の保存波となっている ように見えるが，これらに関しても Froude 数が小さい ために図-14 などからは把握しにくいだけで，実際に はわずかながら波高減衰が発生していることが推測で きる．つまり，本研究が取り扱うような流れを遡る段 波においては Favre などが示した保存波としての状態 は存在し得ないと考えられる.

なお，ここで引用した波高減衰に関する知見は，周 期波を対象にして得られたものである. 本研究で取り 扱う孤立波的な波と周期波では流れを遡る波の波高減 衰に関する厳密な議論は若干異なると推測できる。し かし，孤立波であっても波高減衰に関する性質は定性 的には同様の傾向であると考えられる. そのうえ，工 学的に重要となる終局状態の波形における波高の最大 值は本研究で示した数值解析モデルによっても捉えら れることができているため，この波高減衰に関する詳 細な議論は本研究では行っていない. また，これらの数 值実験は非線形分散波理論式の理論的な特性を示すも のである. 実際の段波問題においては何らかの砕波限 界が存在し，それを超えると砕波することなどに注意 したうえでこの数值実験の結果を取り扱う必要がある.

\section{(6) 波状段波の最大波高に関する数值実験}

ここでは，分散性により波高增幅した結果至る波状 段波の最大波高の性質を調べることを目的とした数值 実験を行った。

まず, Froude数を 0.25 , ゲートの降下速度 $V_{g}$ を 0.095 $\mathrm{m} / \mathrm{s}$ に固定し，ゲートを水に浸す前の水深 $h_{0}$ を 0.10 $0.70 \mathrm{~m}$ まで変化させる条件を与えて長距離伝播させる 数值実験を行った.

図-16 は $80 \mathrm{~m}$ の数值水槽を 60 秒間, 前述のそれぞ れの実験条件で伝播させた結果から得られ最大值を示 したものである. 図中の縦軸の $\eta_{\max }$ は各実験ケースに おける波高の最大值である.この図から，波状段波の 最大波高は水深に依らず，その波高（波高水深比）は 同一になることが分かる. 




図-16 Froude 数, ゲート降下速度を一定として水深 $h_{0}$ を 変化させた場合の波状段波の最大波高

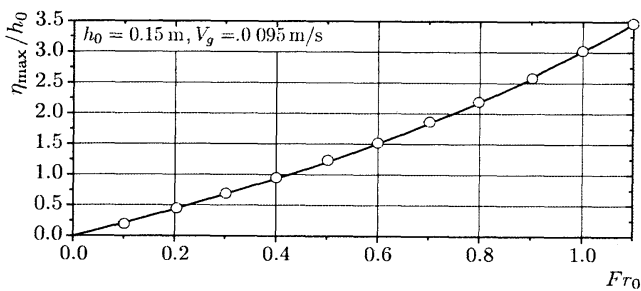

図-17 流れの強さと波状段波の最大波高の関係

つぎに，ゲートを水に浸す前の水深 $h_{0}$ を $0.15 \mathrm{~m}$ と ゲートの降下速度 $V_{g}$ を $0.095 \mathrm{~m} / \mathrm{s}$, ゲートの降下開始 位置 $a_{s}$ を $0.15 \mathrm{~m}$ に固定し, Froude 数を $0.05 \sim 1.10$ ま で 0.05 間隔で変化させて長距離伝播させる数值実験を 行った。

図-17 は, $80 \mathrm{~m}$ の数值水槽を 60 秒間伝播させる数值 実験から得られた各実験条件毎の最大波高を示したも のである. この図から Froude 数が大きくなるに従い終 局的な波形の波高も高くなっていることがわかる.す なわち波状段波の波高水深比の最大値は，ゲート降下 速度 $V_{g}$ やゲートの降下開始位置 $a_{s}$, ゲートを水に浸す 前の水深 $h_{0}$ に依存せず, Froude 数によってのみ決ま ると言える.

\section{6. おわりに}

ゲートを有する河川においては，洪水防御のための ゲート操作や誤動作によるゲートの急閉鎖などを起因 とした段波の発生が予想される. そのため, ゲートの 閉鎖に伴い発生する段波の特性を把握することは, 工 学的に重要であると考えられる. 本研究では, この点 に着目して，これらに関する水理実験とその数値計算 を行った.

まず，スルースゲートの流量係数の検証に関する水 理実験を行い, Henry の流量係数の理論解と著者らの 水理実験が良く一致することを確認した. ただし，この 式を数値計算に適用する際には, 流量係数 $C$ が 0 に漸 近するような条件の取り扱いを慎重に行う必要がある.

つぎに，定常の河川流を模擬した流れの場において， スルースゲートを自由落下させる急閉の実験ケースや モーターを利用して等速度でゲートを落下させる緩閉
の実験ケースのもとで発生する段波に関する水理実験 を行った. 急閉の実験ケースでは, 典型的な波状性を伴 う段波が発生することを確認した。 一方, 緩閉の実験 ケースでは, ゲートの閉鎖方法の違いにより波状性を 伴う段波となる場合とそうでない場合があった. ゲート の閉鎖後の間もない段階から波状性を伴う段波である か否かの判定は，ゲートの操作方法に関するパラメー タ $V_{\mathrm{g}} / \sqrt{g a_{\mathrm{s}}}$ を用いることで可能なことを示した.

そして, 非線形分散波理論式（分散性を考慮した浅 水理論式）を基礎式とする数值解析モデルを構築し，水 理実験の再現計算を行ったところ，いずれの実験ケー スも良好な精度で再現できた．段波の解析を精度良く 行うためにはその波状性を考慮する必要があるが, 従 来までの河道内の段波の数值計算に関する研究例は浅 水理論式を適用したものがほとんどである。この理論 式では段波の波状性を考慮できないために非線形分散 波理論式を用いた計算と比べ，最大波高は過小に，段 波波速は過大に評価される問題がある. 今後, この種 の問題を取り扱い，良好な精度で波速，最大波高など を計算をするためには本研究で示したように非線形分 散波理論式を基礎式とする必要があると考えられる.

最後に, この数值解析モデルを利用して, ゲートの 閉鎖方法の違いが伝播に伴う変形過程や終局的な波形 の波高に及ぼす影響について考察することを目的とし た数值実験を行った. その結果, 同じ Froude 数の条件 下ではゲートの閉鎖方法によって変形過程は異なるも のの, いずれの閉鎖方法によっても最終的には同一波 高まで波高を増幅して伝播することが分かった．ただ し，分散性による波高の増幅が完了して波形の変形が 安定した後は, 流れの影響を受けるためその波高は伝 播するにしたがい減衰し，保存波とはならないことを 示した.

謝辞： 本研究を遂行するにあたり，防衛大学校建設 環境工学科 藤間功司助教授には, 終始懇切なるご指導 を賜った. (株) エコー (研究当時 東海大学技術員) 岩瀬 浩之氏には貴重なご助言を頂いた. 研究当時東海大学 大学院生だった吉川 智之君, 工学部土木工学科 4 年生 諸君には水理実験で尽力してもらった。 また，査読者 の方々には本論文の内容向上のための有益なご指摘を 頂いた.ここに記して感謝の意を表します.

\section{参考文献}

1）石川 忠晴 : 同氏との霞ヶ浦に関する談話.

2) Henry, H.R.:Discussion of Diffusion of submerged jets, Transaction, ASCE, Vol.115, pp.687-694, 1950.

3) Bazin, H. : Mém. divers Savants a L'Acad des SCi. 19., p.495, 1865.

4) Boussinesq, J. : Théorie des ondes et des remous qui se propagent le long d'un canal rectangulaire horizontal, en communiquant an liquide contenu dans ce canal 
de vitesses sensiblement pareilles de la surface anfond, Liouvilles J. Math., Vol.17, pp.55-108, 1872.

5) Favre, H.:Etude theorique et experimental des ondes de translation dans les canaux decouverts. Dunod, p.150., 1935.

6) Keulegan, G.H. and Patterson, G.W. : Mathematical theory of irrotational translation waves, J. Res. Nat. Bur. Standards., Vol.24, pp.47-101, 1940.

7) Benjamine, T.B. and Lighthill, M.J.:On Cnoidal waves and bores, Proc. Roy. Soc., Vol.224, pp.448-460, 1954.

8) Chester, W.: A model of the undular bore on a viscous fluid, J. Fluid Mech., Vol.24, pp.367-377, 1966.

9) Johnson, R.S. : A non-linear equation incorporating damping and dispersion, J. Fluid Mech., Vol.42, pp.4960, 1970 .

10) Johnson, R.S. : Shallow Water Waves on a Viscous Fluid - The Undular Bore, Phys. Fluids, Vol.15, No.10, pp.1693-1699, 1972.

11) Peregrine, D.H. : Calculations of the development of an undular bore, J. Fluid Mech., Vol.25, pp.321-330, 1966.

12) Peregrine, D.H. : Long waves on a beach, J. Fluid Mech., Vol.27, pp.815-827, 1967.

13) Korteweg, D.J. and DeVries, G. : On the change of form of long waves advancing in a rectangular canal and on a new type of long stationary waves, Phil. Mag. (V), Vol.39, No.240, pp.422-443, 1895.

14) 後藤 智明:アーセル数が大きい場合の非線形分散波の方 程式, 土木学会論文集, 第 351 号, pp.193-201, 1984.

15) 室田 明, 岩田好一朗 : 段波の変形に関する研究, 土木学 会論文集, 第 160 号, pp.49-58, 1971.

16) 後藤 智明:津波の線形, 非線形および波数分散現象, 1999 年（第 39 回）水工学に関する夏期講習会講義集 B コー ス, p.B-9-12, 1999.

17）松富 英夫：移動跳水（波状段波非）発生条件の検討, 第 33 回水理講演会論文集, pp.271-276, 1989.

18）岩崎 敏夫, 阿部 至雄, 橋本 潔: 津波の河川遡上に関する数 值計算の実際, 第 23 回海岸工学講演会論文集, pp.437-442, 1976.

19）岩崎 敏夫, 阿部 至雄, 橋本 潔: 河川津波の特性に関する 研究, 第 24 回海岸工学講演会論文集, pp.74-77, 1977.

20）岩崎 敏夫, 阿部 至雄, 橋本 潔: 湾奥に位置する河川での 津波の遡上に関する数値解析, 第 25 回海岸工学講演会論 文集, pp.137-140, 1978.

21）岩佐 義朗, 多田 彰秀: 不連続部を含む時間的変化の急な 流れの数値シミュレーション, 第 29 回水理講演会論文集, pp.663-668, 1985.

22) 中村 茂, 福嶋 祐介：段波の一次元不定流解析, 第 33 回 水理講演会論文集, pp.265-270, 1989.

23) 後藤 智明, 首藤 伸夫：河川津波の遡上計算, 第 28 回海 岸工学講演会論文集, pp.64-68, 1981.
24）宮崎 知与, 史 亜傑：1993 年北海道南西沖地震津波の河川 遡上痕跡調査とその水位再現検討, 自然災害科学, pp.179189, 1997.

25）松冨 英夫, 浅田 宏, 佐藤隆志: 移動床におけるダム破壊 流れの氾濫計算, 第 28 回水理講演会論文集, pp.827-831, 1984.

26）土屋 義人, 山下 隆男, 今塩 宏之 : 水平粗面上での bore front の伝播特性, 第 34 回海岸工学講演会論文集, pp.192196, 1987.

27) Tsuji, Y. and Yanuma, T. and Murata, I. and Fujiwara, C. : Tsunami Ascending in Rivers as an Undular Bore, Natural Hazards 4, pp.257-266, 1991.

28）磯部 雅彦, 高橋 重雄, 余 錫平, 榊山 勉, 藤間 功司, 川崎 浩司, 蒋 勤, 秋山 実, 大山 洋志: 数值波動水路の耐波設 計への適用に関する研究-VOF 法基本プログラムの作 成一, 海洋開発論文集 第 15 巻,pp.321-326,1999.

29）数値波動水路の耐波設計への適用に関する研究会：海域 施設の耐波設計に適用できる数值波動水路 (CADMASSURF) の研究・開発とその将来展望, 土木学会論文集, No.705/II-59, pp.1-17, 2002.

30) 高橋俊彦, 藤間 功司, 朝倉 良介, 池谷 毅: 数值波動水路 の段波実験への適用, 海洋開発論文集, 第 17 巻, pp.281286,2001 .

31）たとえば, 椿 東一郎：水理学 II, 森北出版, 272p., 1974.

32）たとえば, 後藤 智明: 津波の線形, 非線形および波数分 散現象, 1999 年（第 39 回）水工学に関する夏期講習会講 義集 B コース, p.B-9-12, 1999.

33) Madsen, P.A. and Sørensen, O.R. : A new form of the Boussinesq equations with improved linear dispartion characteritics, Part 2, A slowly-varying Bathymetry, Coastal Eng., Vol.18, pp.183-204, 1992.

34) Beji, S. and Nadaoka, K. : A formal derivation and numerical modelling of the improved Boussinesq equations for varing depth, Ocean Eng., Vol.23, pp.691-704, 1996.

35) 岩瀬 浩之, 見上 敏文, 後藤 智明, 藤間 功司: 津波の伝播 計算を対象とした非線形分散長波式の比較, 土木学会論文 集, No.705/II-59, pp.129-138, 2002.

36) 岩瀬 浩之, 見上 敏文, 後藤 智明: 非線形分散波理論を用い た実用的な津波計算モデル, 土木学会論文集, No.600/II44, pp.119-124, 1998.

37) 原 信彦, 岩瀬 浩之, 後藤 智明：非線形分散波理論式に関 する多段階混合差分スキームの提案, 海岸工学講演会論文 集, 第 45 巻, pp.26-30, 1998.

38）たとえば, 椹木 亨: 河口閉そく機構に関する基礎的研究 （第 1 報），第 12 回海岸工学講演会講演集, pp.162-167, 1965 .

39）佐藤 道郎：不等流を遡る波の波高変化に関する基礎的研 究, 土木学会論文報告集, 第 242 号, pp.15-29, 1975.

(2002. 8. 7 受付)

\section{EXPERIMENTAL AND NUMERICAL STUDY ON HYDRAULIC BORE GENERATED BY GATE-OPERATION}

\section{Hiroyasu YASUDA, Tadashi YAMADA and Chiaki GOTO}

Laboratory experiments and numerical simulations were conducted to investigate the characteristics of bores generated by gate-operation. The laboratory tests showed that the gate operation method affected the generation of undular bore, then the condition of immediate formation of undular bore was formulated by a parameter of gate-operation. The numerical simulation with the non-linear dispersive wave theory accurately reproduced the waveform and celerity observed in the laboratory experiments. Furthermore, an influence of gate operation method on the deformation process and the amplitude of undular bore was considered by the numerical experiments. 